\title{
Manuscripts and Printed Texts of the Silesian-Małopolska Compilation
}

\section{$1 \quad$ Sources and Contents of the Weichbild}

This project begins with a closer look at the sources of the Magdeburg Weichbild. As we know it to be a compilation, the first step will be to mark out its components. In general, it is possible to distinguish two major branches of the Weichbild, the vulgate used in Eastern Germany and a version prepared for users in the Kingdom of Poland. Traditionally, the latter has been referred to as Konrad of Opole's compilation. In this study, however, I will refer to it as the Silesian-Matopolska compilation, in order to make a clear distinction between that source and Weichbild's Polish branch as a whole, which, as I will argue, does not rely exclusively on Konrad of Opole's autograph.

\subsection{Konrad of Opole's Compilation or the Silesian-Matopolska Compilation: A Question of Terminology}

Although this study deals primarily with the Latin Weichbild, it would be unwise to ignore the corresponding German sources. This raises the problem of terminology, that is, naming the compilation which comprises all of the manuscripts of that group. Most scholars believe that the compilation is the work of Konrad of Opole. ${ }^{1}$ However, the text in the Cracow manuscript (BJ 169), attributed to Konrad of Opole, cannot be the archetype of the compilation. This is proven by the fact that some passages (provisions) of the Henryków MS (II F 8), also of Silesian provenance, are slightly closer to the

1 Ernst Th. Gaupp, Das alte Magdeburgische und Hallische Recht. Ein Beitrag zur deutschen Rechtsgeschichte (Breslau, 1826), pp. 193-199; Paul Laband, ed., Magdeburger Rechtsquellen. Zum akademischen Gebrauch herausgegeben (Königsberg, 1869), p. 38; Wacław Korta, "Rola kulturalna średniowiecznej kancelarii" [The Cultural Role of the Medieval Chancery], in: Studia z dziejów kultury i ideologii ofiarowane Ewie Maleczyńskiej w 50 rocznicę pracy dydaktycznej i naukowej [Studies in History and Ideology: A Festschrift in Honour of Professor Ewa Maleczyńska to Mark 5 o Years of Her Academic and Teaching Career] (Wrocław - Warszawa Kraków, 1968), p. 69; Zygfryd Rymaszewski, tacińskie teksty Landrechtu Zwierciadta Saskiego $w$ Polsce. Versio Vratislaviensis, versio Sandomiriensis, Łaski [Latin Texts of the Sachsenspiegel Landrecht in Poland: Versio Vratislaviensis - versio Sandomiriensis - Łaski] (Łódź, 1975), p. 9, Notes 3 and 4, p. 10. 
earlier sources of the Weichbild. ${ }^{2}$ If that is the case, how certain can we be that Konrad of Opole was indeed the author of the compilation preserved in the manuscripts dedicated to Cracow (1308) and to Henryk Gusvelt (the Henryków MS of 1306)? ${ }^{3}$ That claim is corroborated by the following argument. First, it is pointed out that the Weichbild compilation is a companion piece to the Sachsenspiegel, which was written (hat gesriben) by magister (Master) Konrad (Henryków Ms), and - more precisely - by Konrad of Opole (Cracow ms). Those are the names mentioned in the Prologues. Second, as Ernst Th. Gaupp points out, the ortyl (Urteil) appended to the Weichbild has the names 'Konrad' (of Opole?) and 'Henryk' (Gusvelt?) inscribed for the litigants, while they are not mentioned in the text of that ortyl in the Brzeg (Brieg) Codex. ${ }^{4}$ The two names are clearly suggestive of Konrad of Opole and Henryk Gusveld, but that is not sufficient evidence to draw the firm conclusion that Konrad of Opole was actually the author of the Weichbild, not merely a copyist. The Silesian provenance of the Henryków Ms has been established beyond any doubt (see Section 2.1). The same can be said about other key 14th-century texts, like the Magdeburg's Legal Instructions for Wroctaw (Rechtsmitteilungen Magdeburgs für Bres(au) and the Sachsenspiegel. The Silesian origin of the Weichbild compilation in the Cracow ms has been firmly established. ${ }^{5}$ Therefore, the term 'Silesian-Małopolska' seems to be the most appropriate designation, as it refers

2 The argument rests on three pieces of evidence: 1) Article 1 in the Cracow MS contains the phrase: Di ratman legen ir burtdinc uz swenne so si wellen mit der wizzegisten rate. It is missing in the Henryków MS and in the Magdeburg's Legal Instructions of 1261, and in Magdeburg Bench Law; 2) Article 80 of the Cracow ms leaves out the reference to the Burggraf of Magdeburg: In des borchgreuen dinge zů Meydeburch mac ein man ..., whereas this information can be found in the Henryków MS and in the Magdeburg's Legal Instructions of 1295 (in F. Ebel's edition of ${ }_{1295} \mathrm{Wr}$.); and 3) Article 88 of the Cracow ms leaves out the detail of the juryman being exposed to insults, which can be found in the Henryków Ms and in Magdeburg's Legal Instructions of 1295: Ob ein schepphe in gehegeteme dinge uf der bank mit vnbillichen worten van einem manne misshandelet worde ... (in F. Ebel's edition). See Maciej Mikuła, "Das Magdeburger Weichbildrecht in seiner schlesisch-kleinpolnischen Fassung. Anmerkungen zur Autorschaft und Textevolution", in: Kulturelle Vernetzung in Europa. Das Magdeburger Recht und seine Städte. Wissenschaftlicher Begleitband zur Ausstellung »Faszination Stadt«, eds. Gabriele Köster, Christina Link, Heiner Lück (Sandstein Kommunikation, 2019), pp. $147-165$.

3 The Henryków Ms itself is of a later date, see Chapter 1.2.1.

4 Gaupp, Das alte Magdeburgische und Hallische Recht, pp. 198-199; and Johann E. Böhme, ed., Diplomatische Beyträge zur Untersuchung der schlesischen Rechte und Geschichte, 2.2 (Berlin, 1775), p. 123 (3).

5 On the role of Silesia in the dissemination of the Saxon-Magdeburg Law, see Elisabeth Nowak, Die Verbreitung und Anwendung des Sachsenspiegels nach der überlieferten Handschriften, Dissertation zur Erlangung der Doktorwürde der Philosophischen Fakultät der Universität Hamburg (Hamburg, 1965) [typescript], pp. 323-324. 
both to the origin of those texts (Silesia) and the territorial scope of their reception and subsequent evolution (Małopolska). The German Weichbild from that compilation became the basis for the Latin translation, whose author - Konrad of Sandomierz - is named explicitly in the sources. ${ }^{6}$ Taking into account the translator's background and - as I will attempt to demonstrate in the following discussion - the crucial role of Cracow in the evolution of the Latin Weichbild, the term 'Silesian-Małopolska compilation' can be extended to cover the Latin progeny of the Silesian German-language corpus (associated with Konrad of Opole) - in particular, the versio Sandomiriensis.

Of crucial significance to the history of the Weichbild in Poland is the Cracow Ms, or - more precisely - the Cracow City Council MS (BJ 169), whose text is representative of the Silesian-Małopolska compilation. It is markedly different from the vulgate because its author draws on a range of sources besides the Weichbild itself: namely, the Magdeburg's Legal Instructions for Wroctaw (Rechtsmitteilungen Magdeburgs fur Breslau) of 1261 and 1295; the Magdeburg Bench Law (Magdeburger Schöffenrecht); the Constitution of Courts (Rechtsbuch von der Gerichtsverfassung); and the Sachsenspiegel. The Weichbild vulgate had never been popular in the Kingdom of Poland, at least not until 1535 when Mikołaj Jaskier published a new, authorized version of the Magdeburg Law based mainly on the German vulgate. The differences between the contents of the two compilations are presented in Table 1.

\subsection{Magdeburg Bench Law (Magdeburger Schöffenrecht) and Magdeburg's Legal Instructions for Wrocław (Rechtsmitteilungen Magdeburgs für Breslau) of 1261}

As Paul Laband has demonstrated, the author of the Silesian-Małopolska compilation gave the pride of place in his Weichbild to the Magdeburg Bench Law (MSR). It consists of $5^{2}$ articles, ${ }^{7}$ enhanced by numerous revised provisions from Magdeburg's Legal Instructions for Wroctaw of 1261, borrowings from the Sachsenspiegel, ${ }^{8}$ and a group of original entries. The text of the Cracow Ms

6 Stanisław Kutrzeba, Historia źródet dawnego prawa polskiego [A History of the Sources of Old Polish Law], 2 (Lwów - Warszawa - Kraków, [1926]), p. 210.

$7 \quad 5^{2}$ articles in the manuscript form the Wrocław University Library shelfmark II Q 3 .

8 In his edition of the Weichbild, based on the vulgate, Mikołaj Jaskier glossed with references to the Sachsenspiegel, see: Zygfryd Rymaszewski, Eacińskie teksty Landrechtu Zwierciadta Saskiego w Polsce. Jaskier - tekst gtówny i noty marginesowe, [Latin Texts of the Landrecht of the Sachsenspiegel in Poland: Jaskier - the Main Text and Marginal Notes] (Łódź, 1985), p. $205 \mathrm{ff}$. His intention was to enable his readers to consult both law sources and to indicate which regulations are identical and which are complementary. However, all too often, the cross references are inaccurate. This is true both of the references from the Sachsenspiegel to the Weichbild (ibid., p. 207) and the other way round, as illustrated by the examples in Table 2. 
TABLE 1 The contents of Magdeburg's Legal Instructions for Wroctaw (1261 and 1295), Magdeburg Bench Law, and the Constitution of Courts in selected texts of the Weichbild

\begin{tabular}{|c|c|c|c|c|}
\hline Text & $\begin{array}{l}\text { Magdeburg } \\
\text { Bench Law } \\
\text { (MSR) }\end{array}$ & $\begin{array}{l}\text { Magdeburg's Legal } \\
\text { Instructions for } \\
\text { Wroctaw of } 1261\end{array}$ & $\begin{array}{l}\text { Magdeburg's Legal } \\
\text { Instructions for } \\
\text { Wroctaw of } 1295\end{array}$ & $\begin{array}{l}\text { The Constituti } \\
\text { of Courts (RG) }\end{array}$ \\
\hline $\begin{array}{l}\text { BJ } 169 \text { and } \\
\text { II F } 8\end{array}$ & $\begin{array}{l}\text { missing: } 3^{\circ} \text {, } \\
5^{\circ}\end{array}$ & missing: $65,72^{\mathrm{a}}$ & $\begin{array}{l}23 \text { Articles } \\
\text { transposed into } \\
17 \text { Articles }\end{array}$ & $\begin{array}{l}6-15 ; 16 \S 3 \\
17-8\end{array}$ \\
\hline BJ 168 & $\begin{array}{l}\text { missing: } \\
3 \mathrm{O}^{\mathrm{b}}\end{array}$ & $\begin{array}{l}\text { missing: } 44 \S 2,45 \\
55^{-68^{c}}\end{array}$ & $\begin{array}{l}23 \text { Articles } \\
\text { transposed into } \\
17 \text { Articles }^{\mathrm{d}}\end{array}$ & $\begin{array}{l}6-15 ; 16 \S 3 ; \\
17-8^{\mathrm{e}}\end{array}$ \\
\hline $\begin{array}{l}\text { Weichbild } \\
\text { vulgate: ed. } \\
\text { Daniels \& } \\
\text { Gruben }\end{array}$ & $\begin{array}{l}\text { missing: } \\
3,15,20 \\
30,32,34, \\
3^{8}-39^{\mathrm{f}}\end{array}$ & $\begin{array}{l}\text { missing: } 44 \S 2 \text {, } \\
45^{-5} 5^{\circ}, 5^{2}, 63^{-69} \text {, } \\
75,76 \S 1,77^{\mathrm{g}} \\
\text { plus Articles } 6,22 \text {, } \\
53,54 \text { (due to gaps } \\
\text { in the MSR) }\end{array}$ & $\begin{array}{l}\text { Articles } 1-4,6-8 \text {, } \\
13 \text {, and } 16\end{array}$ & $\begin{array}{l}\text { Articles } 1-27 \\
\text { (all) }\end{array}$ \\
\hline
\end{tabular}

a In the German texts the contents of Article 72 appear only in an abbreviated and thoroughly modified version in Article 53. Article 65, set apart in F. Ebel's edition, comprises no more than the address and signature of the Magdeburg lay judges. For E.Th. Gaupp this is further proof of the two-stage formation of the Legal Instructions, in 1261 and 1283 (cf. Gaupp, Das alte Magdeburgische und Hallische Recht, pp. 48-49).

b Article 50 of the Magdeburg Bench Law is missing from the Cracow Ms; it appears, though, as Article CIX in the Wawel Ms.

c These are Articles 55-70 following the numbering scheme in Paul Laband's Magdeburger Rechtsquellen. Zum akademischen Gebrauch herausgegeben (Königsberg, 1869), Gustav Adolf Tzschoppe and Gustav Adolf Stenzel's Urkundensammlung zur Geschichte des Ursprungs der Städte und der Einführung und Verbreitung deutscher Kolonisten und Rechte in Schlesien und der Oberlausitz (Hamburg, 1832), No. LVI, pp. 351-363); and Gaupp's Das alte Magdeburgische und Hallische Recht, pp. 230-249.

d Article 14 duplicated in Article CVII.

e Articles 6-15 removed and placed ahead of Sachsenspiegel.

f Article 29 of the Magdeburg Bench Law, missing from the Cracow Ms, reappears as Article 43 of the vulgate. Meanwhile, Article 50 of the Magdeburg Bench Law, missing from the Cracow Ms, is mirrored by Article 62 of the vulgate.

g They are Articles $63-71,77,78 \S 1,79$ according to the numbering scheme in P. Laband's, G.A. Tzschoppe, and G.A. Stenzel's, and E.Th. Gaupp's editions. 
TABLE 2 References to the Sachsenspiegel in the marginal glosses of Mikołaj Jaskier's edition of the Weichbild

\begin{tabular}{|c|c|c|c|c|}
\hline $\begin{array}{l}\text { BJ } \\
169\end{array}$ & MSR & JIM & $\begin{array}{l}\text { Reference } \\
\text { to JSSp }\end{array}$ & Type of reference \\
\hline 13 & 35 & LXIII & II 24 , III 5 & $\begin{array}{l}\text { regulations broadening the scope of lien and } \\
\text { alienation of property }\end{array}$ \\
\hline 14 & 14 & LVII & II 21,24 & $\begin{array}{l}\text { additional regulations concerning land } \\
\text { rent (II 21), incorrect reference II } 24\end{array}$ \\
\hline 25 & 45 & LVIII & I 14 & other regulations concerning family property \\
\hline 29 & 44 & LI & I 8 & incorrect reference \\
\hline 31 & 8 & LXXXIII & I 49 & $\begin{array}{l}\text { additional regulations concerning trial by } \\
\text { combat }\end{array}$ \\
\hline 36 & 13 & LXXXVII & I 68 & incorrect reference \\
\hline 37 & 14 & LXXXVIII & I 64 & $\begin{array}{l}\text { additional reference: in SSp I } 62 \text { reference to JIM } \\
\text { Article XXXVIII }\end{array}$ \\
\hline 38 & 31 & XCIX & I 9 & $\begin{array}{l}\text { additional reference: in SSp I } 9 \text { reference to JIM } \\
\text { Article XCIX and CXL }\end{array}$ \\
\hline 40 & 49 & LXIX & II 43 & regulations matching JIM \\
\hline 45 & 36 & $\mathrm{LX}$ & III 83 & additional reference \\
\hline 46 & $37-38$ & LXI & I $21,5^{2}$ & $\begin{array}{l}\text { complementary regulations concerning dower } \\
\text { (I } 21 \text {; in II } 21 \text { it is similar to JIM); identical to the } \\
\text { regulations concerning consent of close relatives } \\
\left.\text { to the alienation ( } 5^{2}\right)\end{array}$ \\
\hline
\end{tabular}

JIM - Mikołaj Jaskier, Iuris Municipalis Maideburgensis Liber vulgo Weichbild nuncupatur ... (Samosci, 16o2); JSSp - Mikołaj Jaskier, Iuris Provincialis quo Speculum Saxonum vulgo nuncupatur Libri tres ... (Samosci, 1602).

includes Articles 1-29, 31-49, and 51-52 of the Schöffenrecht - that is, 94 per cent of the Magdeburg Bench Law content. A significant number of the regulations of the Magdeburg Bench Law have their origin in the 1261 Magdeburg's Legal Instructions for Wroctaw. When these are added to the articles taken over directly from the latter, it is revealed that 75 out of $76(77)^{9}$ chapters of the Cracow manuscript (i.e. 99 per cent) reproduce the provisions of the Legal

9 This calculation does not include $\S 65$ (in Friedrich Ebel's edition) because it contains only a list of names of Magdeburg officials; cf. Friedrich Ebel, ed., Magdeburger Recht, Vol. II: Die Rechtsmitteilungen und Rechtssprüche für Breslau, Part 1: Die Quellen von 1261 bis $145^{2}$ (Köln - Wien, 1989), p. 12. 
Instructions. By comparison, the author of the manuscript of the High Court of German Law at the Royal Castle of Wawel (BJ 168) borrowed more material directly from the Magdeburg Bench Law (even though Article 50 was removed to the so-called partes extravagantes of the Weichbild ${ }^{10}$ the rate is it still at 96 per cent), but left out more provisions from the 1261 Legal Instructions (i.e. used 77 per cent). The fact that most of the provisions came from the Sachsenspiegel may have been the reason for this type of revision in a manuscript volume that contained both the Weichbild and the Sachsenspiegel. Eight provisions of the Magdeburg Bench Law are missing from the vulgate (those provisions that are taken over from the Magdeburg Bench Law make up 85 per cent), while material from the ${ }_{1261}$ Legal Instructions amounts to 71 per cent. However, as already noted, much of the 1261 Magdeburg's Legal Instructions for Wroctaw had already been absorbed into the Magdeburg Bench Law. Unfortunately, the sources in Paul Laband's edition offer little that would help us to ascertain which version was actually used by the author of the Silesian-Małopolska compilation.

\subsection{Constitution of Courts (Rechtsbuch von der Gerichtsverfassung), Magdeburg's Legal Instructions for Wrocław (Rechtsmitteilungen Magdeburgs für Breslau) of 1295, and Other Sources}

As the research of Paul Laband has shown, the original core of the Constitution of Courts (RGV) were Articles 6-15 (as numbered in the later, complete version), supplemented by Articles 16-18. Laband points out that the latter (or more precisely, Articles 17 and 18, plus $16 \S 3^{-18)}$ were of greater practical importance. They were incorporated into the Silesian-Małopolska Weichbild, while the more theoretical points concerning translatio imperii, the accountability of the emperor, and the question of appealing the judgements of the Magdeburg Lay Bench in Articles 6-15 are relocated to the end, after the formula of the Jewish oath (that material amounted to 42 per cent of the complete Constitution of Courts). The Weichbild vulgate contains the whole of Articles 1-27 of the Constitution of Courts, and was later expanded to include Articles 28-41 from the Sachsenspiegel. ${ }^{11}$ In addition, the Silesian-Małopolska

10 This is a section added to the main text by the copyist just ahead of the Jewish oath. In this way, he probably wanted his manuscript to have nearly as many chapters as the basic text after some provisions from the Sachsenspiegel had been removed from Wawel MS (BJ 168). Cf. Ferdinand Bischoff, "Beiträge zur Geschichte des Magdeburgerrechts", Sitzungsberichte der Kaiserlichen Akademie der Wissenschaften. Philosophisch-Historische Classe 50/4 (1865), 335-41.

11 Renate Schelling, "Magdeburger Schöffensprüche und Magdeburger Weichbildrecht in urkundlicher und handschriftlicher Überlieferung", in: Hanse, Städte, Bünde. Die sächischen Städte zwischen Elbe und Weser um 1500. Ausstellung Kulturhistorisches Museum Magdeburg 28. Mai bis 26. August 1996. Braunschweigisches Landesmuseum. 


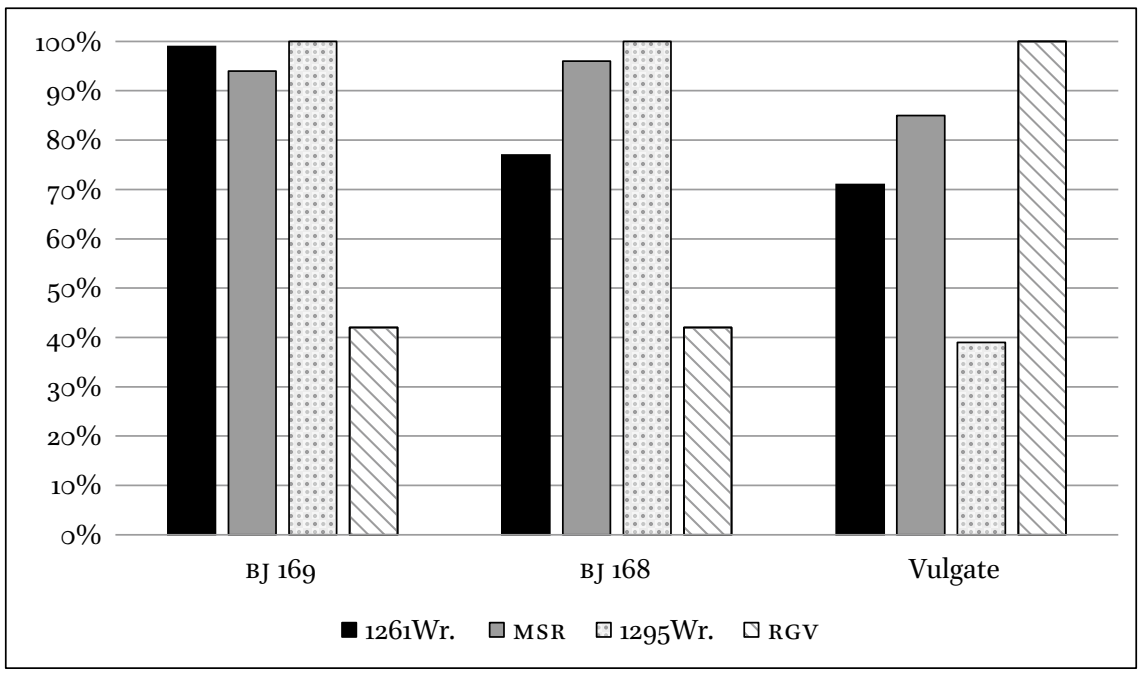

FIGURE 1 Borrowings from Magdeburg's Legal Instructions for Wroctaw of 1261 and 1295, the Magdeburg Bench Law (MSR) and the Constitution of Courts (RGV) in the Weichbild manuscripts

compilation includes all of the 1295 Legal Instructions for Wroctaw, whereas only nine articles in the vulgate come from that source (39 per cent). ${ }^{12}$ In the Silesian-Małopolska compilation, there are also a number of articles whose provenance is unclear, including three with procedural formulas that can also be found in the Berlin manuscript, published by Hermann Wasserschleben. ${ }^{13}$ Both the Weichbild vulgate as well the Silesian-Małopolska compilation include the formula of the Jewish oath (Article 108). ${ }^{14}$

The extent of the borrowings between the sources under discussion are shown graphically in Figure 1.

Ausstellungszentrum Hinter Aegidien 17. September bis 1. Dezember 1996, 1, ed. Matthias Puhle, (Magdeburger Museumsschriften) 4/1 (Magdeburg, 1996), p. 118.

This does not include $\S 24$ (in F. Ebel's numbering scheme) as it contains only the address and a list of names of Magdeburg officials, i.e. a kind of content that for obvious reasons was edited out of the Weichbild (Ebel, Magdeburger Recht, Vol. II: Die Rechtsmitteilungen und Rechtssprüche für Breslau, Part 1, p. 20).

13 Article 52 matches Article LXXVI, and Article 54 - Article LXXVIII. Moreover, whereas the opening of Article $5^{1}$ in the Cracow Ms (BJ 169) is a borrowing from the Magdeburg Bench Law, the final section is identical to Article LXxvir of the Berlin Ms. Cf. Hermann Wasserschleben, ed., Sammlung deutscher Rechtsquellen, 1 (Giessen, 186o), pp. 125-126. According to F. Bischoff (Beiträge zur Geschichte, p. 282), the procedural formulas of Article 51, $5^{2}$ and 54 can also be found in the Brzeg Codex (a collection of ortyle). Cf. Böhme, Diplomatische Beyträge, p. 122, No 7; p. 123, No. 2 and 3; p. 124, No. 1.

14 Cf. Jana Pacyna, Mittelalterliche Judenrechte. Norm und Anwendung im Magdeburger Rechtskreis (1250-1400) (Halle/Saale, 2015), pp. 151-163. 


\subsection{The Impact of the Sachsenspiegel}

The dependence of the Weichbild on the Sachsenspiegel is a matter of considerable complexity and has to be analysed in light of two categories: indirect borrowing (via the Legal Instructions, the Magdeburg Bench Law, and the Constitution of Courts) and direct borrowings. ${ }^{15}$ At this point, let it be noted that the Cracow Ms contains no passages taken over directly from the Sachsenspiegel (SSp); it has plenty of the SSp regulations handed down by the 1261 Legal Instructions. The extent of those borrowings is presented in Table 3.

TABLE 3 Provisions of the Sachsenspiegel incorporated into Cracow MS (BJ 169) via Magdeburg's Legal Instructions for Wroctaw of 1261

$\begin{array}{lllll}\text { Cracow MS } & \text { Wawel Ms } & \text { Weichbild } & \text { Magdeburg's Legal } & \text { Sachsenspiegel (Spp) }^{\mathrm{a}} \\ (\text { (BJ 169) } & \text { (BJ 168) } & \text { vulgate } & \text { Instructionsfor } \\ & & & \text { Wroctaw of } 1261 \\ & & & (1261 \text { Wr. })\end{array}$

\begin{tabular}{|c|c|c|c|c|}
\hline $5^{6^{\mathbf{b}}}$ & - & - & ${ }_{1261}$ Wr. 68 in fine $[70]^{\mathrm{c}}$ & $\begin{array}{l}\text { SSp I } 63 \S 4 \text { in fine., } 64 \text {, } \\
65 \S_{1}\end{array}$ \\
\hline 57 & - & - & 1261 Wr. $69[71]$ & SSp I $65 \S 2$ \\
\hline $5^{8}$ & - & - & 1261 Wr. $70,71[72,73]$ & SSp I $65 \S 3 ; 68$ § 1 \\
\hline 59 & - & - & 1261 Wr. $55^{-61}$ & $\begin{array}{l}\text { SSp I } 22 \S 4-5 ; 23,24 \\
25 \S 1-3^{\text {d }}\end{array}$ \\
\hline 60 & - & - & $1261 \mathrm{Wr} .62$ & SSp I $62 \S 8,9$ \\
\hline 61 & - & - & 1261 Wr. 63 & SSp I $62 \S 10,11$ \\
\hline
\end{tabular}

a Following the numbering scheme of Karl A. Eckhardt's edition: Eike von Repgow, Sachsenspiegel. Landrecht, (Monumenta Germaniae Historica. Fontes iuris Germanici antiqui. Nova Series) I.1 (Göttingen - Frankfurt, 1973).

b In his edition of the Magdeburg Lawbook of Pleszew, Witold Maisel observes that Article 52 includes a sentence that is very similar to SSp I 63 § 1 (cf. Witold Maisel, ed., "Prawo magdeburskie miasta Pleszewa" [The Magdeburg Lawbook of Pleszew], Studia i Materiaty do Dziejów Wielkopolski i Pomorza 9/1 (1963), p. 81, Note 16). However, that provision of the Sachsenspiegel is actually incorporated into Article 56 .

c In brackets the numbers of the scheme employed in the critical edition of P. Laband, G.A. Tzschoppe, and G.A. Stenzel, as well as that of E.Th. Gaupp.

d Contrary to the assertion of P. Laband (in Magdeburger Rechtsquellen, p. 94), Article 23 SSp was fully incorporated into $1261 \mathrm{Wr}$.

15 According to Rolf Lieberwirth, the Magdeburg lay judges often drew on various sections of the Sachsenspiegel. See Rolf Lieberwirth, "Magdeburger Recht;" in: Hanse, Städte, Bünde. Die sächsischen Städte zwischen Elbe und Weser um 1500, ed. M. Puhle, 1, (Magdeburger Museumsschreiben) 4 (Magdeburg, 1996), p. 116. 
The copyist of the Wawel manuscript (for the use of the High Court of German Law at Wawel, MS BJ 168) informs the readers about the omission and directs them to the text of the Sachsenspiegel reproduced in the same volume. However, he does copy some of Sachsenspiegel provisions in the so-called partes extravagantes of the Weichbild (I 66 § 3, I 69, in Article CV and III 39 § 1 in Article CX), presumably to fill the gap left after the removal of material referring to the Constitution of Courts from the main body of the Weichbild.

The impact of the Sachsenspiegel on the Weichbild vulgate is quite different. Owing to the complete incorporation of the Constitution of Courts, numerous provisions of the SSp found their way into the Weichbild. As Paul Laband has demonstrated, large chunks of the Weichbild (i.e. Articles 19, 28-41, and 109125) can also be traced back to the Sachsenspiegel. ${ }^{16}$ As Table 3 shows, due to the omission of some provisions of Magdeburg's Legal Instructions for Wroctaw of 1261, which came originally from Sachsenspiegel, the vulgate does not contain some of the Sachsenspiegel material that can be found in the Weichbild of the Silesian-Małopolska compilation.

\subsection{Practical Consequences of the Differences between the Silesian-Matopolska Compilation and the Weichbild Vulgate}

There are three major consequences of the differences between various compilations of the German-language Weichbild. First, the Silesian-Małopolska compilation comprises the complete text of Magdeburg's Legal Instructions for Wroctaw of $1295 \cdot{ }^{17} \mathrm{It}$ addresses a wide range of issues, the following of which are not treated by the vulgate (numbers according to $1295 \mathrm{Wr}$.): confiscation of property (Article 5); accusations in connection with injuring an assailant in self-defence (Articles 9-10); the accusation of a woman of killing or wounding (Article 11); the division of inheritance among sons (Article 12); killing and wounding (Articles 14-15)l proxies in judicial procedure (Article 17); elements of the gerada $^{18}$ (Articles 18-19); exclusion of evidence (Article 20); liability of minors under guardianship (Article 21); oaths in cases of insults (Article 22); and the jurisdiction of municipal courts (Article 23).

16 Schelling, Magdeburger Schöffensprüche, p. 118; Laband, Magdeburger Rechtsquellen, pp. 94, and 110-111. Cf. also comparative analyses of the Weichbild vulgate and the Sachsenspiegel in: Wilhelm von Thüngen, ed., Das sächsische Weichbildrecht nach dem Codex Palatinus Nro. 467. Mit einer Einleitung als Inaugural-Dissertation (Heidelberg, 1837), pp. 23-25; and Gaupp, Das alte Magdeburgische und Hallische Recht, pp. 115-116.

17 Ferdinand Bischoff, "Über einen deutschen Rechtscodex der Krakauer Universitäts-Bibliothek", Sitzungsberichte der Kaiserlichen Akademie der Wissenschaften. Philosophisch-Historische Classe 48/1-2 (1864), 292. 
Second, the Cracow MS acknowledges to a much greater extent the Magdeburg Bench Law (MSR) and Magdeburg's Legal Instructions for Wroctaw of 1261. Although of the two articles of the Magdeburg Bench Law missing from the Cracow Ms, the Weichbild vulgate has one (concerning inheritance left to children; Article 50 of the MSR in Article 62 of the vulgate), it does not include a number of important provisions from the MSR that are mentioned in the Cracow Ms. These provisions are concerned with: the use of false weights and measures (numbering scheme of the Magdeburg Bench Law; Article 3); accusations in connection with injuring or killing (Article 15); the division of the gerada between women and clergymen (Article 20); theft (Article 32); deposits (Article 34); consent of family members to a donation (Article 38); and the effect of second marriages on rules of inheritance (Article 39). Similarly, a considerable number of the provisions of the Legal Instructions of 1261 were not adopted by the vulgate. These include (barring those that were omitted because of their origin in the Magdeburg Bench Law) provisions concerning judicial sentencing (Article $44 \S 2-45$ ); presentation of charges (Article 46); inheritance rights of family members of a man sentenced to death (Article 47); inheritance rights of children and widows (Article 48); the right of minors to choose their guardian (Article 49); the testimony required in cases in which a man has to prove his freedom (Article 50); inheritance debts (Article 52); judicial proceedings and sentencing (Articles 63 and 62); forfeiture of rights in the case of the death penalty having been commuted to a fine (Article 69); seizure of livestock found trespassing (Article 74); debts (Article $76 \S 1$ ); and compensation (Article 77).

Third, whereas the Cracow and other manuscripts tap into the earliest sources of Magdeburg Law, the vulgate is oriented primarily towards the Sachsenspiegel. The publication in tandem of the Sachsenspiegel and a pruned Weichbild by Mikołaj Jaskier in 1535 made the two legal collections equally accessible. However, the assumption that the publication of a complete, authoritative edition of the Sachsenspiegel would make up for its fragments embedded in the Weichbild does not take into account the fact that the latter owed its worth to the unique blend of the Magdeburger Schöffenrecht and the Legal Instructions of 1261 and 1295. There remains the unresolved question of the provenance of the final section (Articles 126-135) of the vulgate. Paul Laband does not refer it back to the Sachsenspiegel, ${ }^{19}$ which makes the assess-

19 Laband, Magdeburger Rechtsquellen, p. 111. The provisions of this section are concerned with attempted wounding (Article 126), non-payment of wergild (Article 127), standard width of public roads (Article 128), sequestration of horses (Article 129), reprieve and commutation of executions (Article 130), payment claims (Article 131), vindication of stolen 
ment of the practical value of the competing compilations of the Weichbild all the more difficult.

\subsection{Summary: The Silesian-Matopolska Compilation as an Urban Law Code}

The foregoing analysis shows that the authorship attribution of the Weichbild used in medieval Poland to Konrad of Opole is essentially conjecture, with no firm evidence to back it up. Konrad of Opole's text is certainly part of the picture, but it is in no way identical to the compilation which began to be disseminated in both German and Latin versions from Silesia and Małopolska in the 13th century. Even if its origin was in Silesia, it was given its distinctive shape in Małopolska - hence the term 'Silesian-Małopolska compilation'. A comparative analysis of sources and texts of the two major compilations - the vulgate and the Silesian-Małopolska manuscripts - shows that the latter was highly receptive to the Magdeburg case law. The Cracow Ms therefore absorbed 99 per cent of the regulations from Magdeburg's Legal Instructions for Wroctaw of 1261, 94 per cent of the Magdeburg Bench Law judgments, and 1oo per cent of the Magdeburg's Legal Instructions for Wroctaw of 1295, while the vulgate took in 71 per cent, 85 per cent, and 39 per cent of those texts, respectively. The vulgate, on the other hand, was more receptive to the legal material from the Sachsenspiegel and the Constitution of Courts (Rechtsbuch von der Gerichtsverfassung). The role of practical demand in the process of modification of the received text in either of the two branches of the Weichbild is not easy to assess or compare. Nevertheless, what can be said with certainty about the Silesian-Małopolska compilation is that it had its origins in the Magdeburg Law; its popularity was connected with the rise of towns; and, finally, it was already subject to modifications at its earliest stage, that is, the appearance of German-language manuscripts.

goods (Article 132), court fees (Article 133), and litigation between Christians and Jews (Articles 134 and 135). These problems are tackled in the Sachsenspiegel, but its approach is different, as shown by the provision concerning the width of public roads. See: SSp II 59 § 3 in Karl A. Eckhardt's edition of 1973; and in: Eike von Repgow, Sachsenspiegel. Die Dresdner Bilderhandschrift Mscr. Dresd. M 32. Textband, ed. Heiner Lück, coop. Thomas Haffner, Marion Perrin, and Jörn Weinert (Graz, 2006), p. 164, f. 2. Cf. also Mikołaj Jaskier's Latin redaction in Iuris Provincialis quo Speculum Saxonum vulgo nuncupatur Libri tres ... (Samosci, 16o2), f. xCII; and the Polish translation of Paweł Szczerbic, Speculum Saxonum, albo prawo saskie i majdeburskie, porzadkiem obiecadta z łacińskich i niemieckich egzemplarzów zebrane. A na polski język z pilnościa i wiernie przetożone [Speculum Saxonum or Saxon and Magdeburg Law, in Alphabetic Order, from Latin and German Copies Collected. A New and Meticulously Accurate Translation into Polish], ed. Grzegorz M. Kowalski, 1, (Bibliotheca Iagiellonica. Fontes et Studia) 29 (Kraków, 2017) p. 218. 


\section{Dynamics of the German Text}

To form a better understanding of the evolution of the Latin texts of the Weichbild, it is necessary to consider its background, the dynamic development of its German prototype within the Silesian-Małopolska compilation.

\subsection{Studies of the Weichbild in the Cracow $\mathrm{MS}$ (BJ 169) and the Henryków Ms (II F 8).}

The Cracow MS of $1308,{ }^{20}$ also known as Konrad of Opole's manuscript, is made up of 309 leaves. It contains a selection of Latin and German texts, namely, the Sachsenspiegel Landrecht and Lehnrecht and the Lübeck Law (in Latin), as well as two parts of the Sachsenspiegel and the Magdeburger Weichbild (in German). ${ }^{21}$ In his major study of the Cracow City Council Ms, Ferdynand Bischoff compared the Cracow Ms (BJ 169) with the text of the Legal Instructions for Wroctaw, the Magdeburg-Görlitzer Law of 1304 , and the Weichbild vulgate. ${ }^{22}$ He notes that the Cracow manuscript not only reproduces the contents of the Legal Instructions (1261), but that it also retains - with a few exceptions - the sequential order of the provisions from the sources. He concludes - in my opinion, rightly - that the divergences from the wording of some of the articles in Magdeburg's Legal Instructions for Wroctaw of 1261 result from the author's use of a different version of that basic text. Paul Laband identified that missing

20 In his A History of the Sources of Old Polish Law, S. Kutrzeba questioned the dating of the Cracow MS and attributed its authorship to a Cracow notary (1337?-1354) (Kutrzeba, Historia źródet, 2, p. 210). His argument, which called for a revision of established dating of the Cracow Ms (BJ 169) by 30 years to 1338, was refuted by Rymaszewski in tacińskie teksty Landrechtu Zwierciadta Saskiego w Polsce. Versio [Latin Texts of the Landrecht of the Sachsenspiegel in Poland. Versio], p. 10, Note 12). The problem was also raised in Theodor Goerlitz's study "Das flämische und das fränkische Recht in Schlesien und ihr Widerstand gegen das sächsische Recht", Zeitschrift der Savigny-Stiftung für Rechtsgeschichte. Germanistische Abteilung 57 (1937), 156. Goerlitz sets down the terminus ad quo at 1292 and the terminus ad quem at a time shortly before 1310 without opting for a more precise date.

21 For a meticulous description of its contents, see Zofia Włodek, Catalogus Codicum Manuscriptorum Medii Aevi Latinorum qui in Bibliotheca Jagellonica Cracoviae Asservantur, 1 (Wrocław, 1980), pp. 155-159; see also the description by Władysław Wisłocki in Inwentarz rękopisów Biblioteki Jagiellońskiej [Inventory of Manuscripts in the Jagiellonian University], 1 (Kraków, 1877-1881), p. 67. For more recent descriptions, see Oppitz's Catalogue, No. 845, pp. 613-614, and Friedrich Ebel and Renate Schelling's "Das lateinische lübische Recht in der schlesisch-polnischen Fassung des 13. Jahrhunderts", Zeitschrift der Savigny-Stiftung für Rechtsgeschichte. Germanistische Abteilung 110 (1993), 95 .

Bischoff, “Über einen deutschen Rechtscodex”, pp. 276-297. 
link as the Magdeburg Bench Law. ${ }^{23}$ Ferdinand Bischoff reacted by reaffirming his claim that the Cracow MS reproduced all of the Legal Instructions of 1295, while compressing some of its provisions into single articles. Furthermore, he contends that the text of the Cracow Ms has its closest match in the Uffenbach MS and that the differences between the two are not sufficiently significant to undermine their inherent affinity. In other words, it is highly unlikely that both texts are independent of one another. They share exactly the same oath formulas (Articles 51-53) and nearly the exact same Jewish oath. While Bischoff rules out the dependence of the Cracow ms on the Weichbild vulgate, ${ }^{24}$ he insists that the Cracow manuscript, the Legal Instructions for Zgorzelec (Görlitz), the Naumburg Codex, and the Uffenbach Ms are all related. He does not rule out that the Weichbild of the Cracow MS was composed c. 1304 (or slightly later) in Silesia or in Cracow, but he expresses doubt about his official character. ${ }^{25}$ In his view, it did not possess that status until it was adopted by the Cracow City Council (in the form of the Cracow Ms).

The composition of that text at the beginning of the 14th century can be explained by reference to the following events. By 1304, an expanded version of Magdeburg's Legal Instructions was already in use in Zgorzelec; one year later, the town started its own book of court records. Głogów (Glogau) acquired its own manuscript of Magdeburg Law in 1314. In Cracow, a book of court records was started c. $1300,{ }^{26}$ rendering the need for a handy copy of the law more pressing than ever. This need was met by Cracow Ms, which, as Zygfryd Rymaszewski observes, contains the full corpus of the Saxon-Magdeburg Law. ${ }^{27}$

As was mentioned in Section 1.1, the text of the Weichbild in the Cracow MS is not identical to the archetype of compilation - if only because it contains passages that are closer to the Henryków ms. The latter, Wrocław University

23 Laband, Magdeburger Rechtsquellen, p. 93ff.

24 Bischoff, "Über einen deutschen Rechtscodex", p. 269.

25 Ibid., p. 297.

26 Bożena Wyrozumska, Kancelaria miasta Krakowa wśredniowieczu [Chancellery of the City of Cracow in the Middle Ages] (Kraków, 1995), p. 56; and Piotr Okniński, "Uwarunkowania początków rozwoju kancelarii miejskich. Przykład Krakowa (do 1312 r.)” [The Origins of Municipal Chancelleries: The Case of Cracow (until 1312)], in: Loca scribendi. Miejsca $i$ środowiska tworzace kulturę pisma $w$ dawnej Rzeczypospolitej XV-XVIII stulecia [Loca scribendi: Sites and Communities Involved in the Creation of the Culture of Writing in the Old Polish Commonwealth in the 15th-18th Century], eds. Anna Adamska, Agnieszka Bartoszewicz, and Maciej Ptaszyński (Warszawa, 2017), pp. 39-40.

27 Rymaszewski, Lacińskie teksty Landrechtu Zwierciadta Saskiego w Polsce. Versio, p. 10; and Edward Potkowski, Książka rękopiśmienna w kulturze Polski średniowiecznej [The Hand-written Book in the Culture of Medieval Poland] (Warszawa, 1984), p. 176. 
Library MS II F 8, is a collection of German sources of municipal law. ${ }^{28}$ It dates back to the turn of the 14th century, or the early $15^{\text {th }}$ century at the latest, and its Silesian provenance is beyond any doubt. ${ }^{29}$ As both texts are closely related, they must have had a common base.

\subsection{The Impact of the Cracow City Council Weichbild: the Wawel MS (BJ 168) and $M S$ BJ $170 a$}

It has been said that the Wawel MS (BJ 168) was granted by King Kazimierz the Great to the Mayor (wójt / Vogt / advocatus) and aldermen of the High Court of German Law at the Royal Castle in Cracow. ${ }^{30}$ It is certainly true that the manuscript was used by the Court. That is attested by, among others, an entry made by Andrzej Czarnisza, mayor and president of the High Court in 1392-1416. ${ }^{31}$ The contents of the manuscript show the pre-eminently practical bias of this law book. ${ }^{32}$ The first detailed description of the manuscript

28 1) The Latin Landrecht of the Sachsenspiegel in the Wrocław version (f.1-38);2) the Lübeck Law (in Latin) (f. 39-43); 3) Das Lehnrecht in the Wrocław version in Latin (f. 45-67); 4) Das Landrecht (f. 68-125); 5) Die Weichbildchronik (f. 126-134); 6) Das Lehnrecht (f. 129157);7) the Weichbild in the Silesian-Małopolska version (f. 158-180);8) Magdeburg's Legal Instructions for Wroctaw (f. 181-19o); and 9) the Magdeburg judgments (ortyle) (f. 190-194).

29 Rymaszewski, Eacińskie teksty Landrechtu Zwierciadta Saskiego w Polsce. Versio, p. 11. This manuscript has been the object of intense scrutiny as shown by the bibliographical list compiled by Oppitz (No. 261, p. 409). However, it should be noted that his list also includes publications that merely mention the Henryków Ms. For a supplementary bibliography and a digitized copy of the manuscript, see the website of the Wrocław University Library, see http://dk.bu.uni.wroc.pl/cymelia/displayDocument.htm;jsessionid=oC8E4EBBFFoE 78Co7ADFCoE96B1FB74B?docId=5002000234 (Accessed: 22 May 2017). Cf. also Ebel and Schelling, Das lateinische lübische Recht, p. 97.

$30 \quad$ Similarly, e.g. F. Bischoff, "Beiträge zur Geschichte", p. 333.

31 Mark Munzinger, "The Text and Textualization of Codex BJ 168: Legal Culture in Transition at the High Court of Magdeburg Law at the Castle of Kraków", Krakowskie Studia z Historii Państwa i Prawa 4 (2011), 30-2.

32 Its list of contents is as follows: 1) Kazimierz the Great's royal charter establishing the High Court of German Law at the Royal Castle in Cracow (f. $1 \mathrm{r} \mathrm{i} \mathrm{v);} \mathrm{2)} \mathrm{indices} \mathrm{(regesta)}$ of the Landrecht and the Weichbild (f. $2 \mathrm{r}-8 \mathrm{r}$ ); 3 ) an extract from the Weichbildchronik (f. 9 r i v); 4) an extract from the Constitution of Courts (f. 9v-12v); 5) the Sachsenspiegel in the Silesian-Prussian version (f. 13v-66v);6) partes extravagantes of the Sachsenspiegel (f. 66v-68v); 7) the Weichbild (f. 68v-87v); 8) three pages of short supplements: a) an entry made by Andrzej Czarnisza, president of the High Court of German Law at the Royal Castle in Cracow (f. 87v); b) an extract from the Decretals of Gregory IX (Articles 3, 52 and 2 -f. 87v); c) an extract from the Weichbild (f. 87v); d) an extract from Codex Justinianeus (Articles 8, 17 and 12 - f. 88r); e) a note concerning the size of the Frankish tan (Fränkische Großhufe) (f. 88r); f) an extract from St John's Gospel (John 1, 1-15- f. 88v); g) the lay judge's oath in Polish and in German (f. 88v). This list of contents follows Włodek, 
was published by Ferdinand Bischoff. ${ }^{33}$ There, he also made the case for the Cracow ms being older than the Wawel Ms. Although this conclusion has been generally accepted, some of his other claims are debatable. For example, Bischoff assumes that Kazimierz the Great, aware of the need of the newly created High Court for its own codex of the Saxon-Magdeburg Law, asked the Cracow City Council for help, as the City of Cracow already possessed of a copy of the law, that is, the Cracow ms (BJ 169). In effect, a new copy, a somewhat modified version of MS BJ 169, was prepared and designated, by the authority of the Cracow High Court, as a basis for a Latin translation, ${ }^{34}$ preserved in the Opatów Ms. Later, the text in that manuscript, he argues, provided the model for Łaski's Statutes. ${ }^{35} \mathrm{~A}$ table where assorted similarities and differences between the texts in question are put side-by-side appears to prove his point. Yet, ultimately, Bischoff's argument fails to convince. The evidence indicates that a large number of provisions in the Wawel Ms are closer to the original sources of the Weichbild (i.e. Magdeburg's Legal Instructions for Wroctaw) than to the Weichbild in the Cracow Ms. ${ }^{36}$ This means that the latter could not be the only basic text for the Wawel Ms. Its more complex origin is further indicated by the fact that the Sachsenspiegel in the Wawel ms belongs to the socalled Silesian-Prussian version, with the addition of partes extravagantes, ${ }^{37}$ while the Sachsenspiegel of the Cracow Ms represents the versio Vratislaviensis. Moreover, there are some clear hints that the text in the Wawel Ms was at least partly collated with the Cracow Ms. The wording of Article 27 offers a strong proof of the dependence of the Wawel Ms on the Cracow Ms. It shows Table 4.

Bischoff's claim about the affiliation of the Opatów Ms (MS Oss., see Section 3.13) and the text of Łaski's Statutes was challenged by Emil Kałużniacki. ${ }^{38}$ Another of his points, the alleged dependence of the Latin translation on the Cracow ms, will be discussed in greater detail in this study (see Chapter 2). What may also prove to be significant in this discussion is the omission in the

Catalogus Codicum, pp. 151-155, which has supplanted the summary enumeration of Wisłocki (Inwentarz, pp. 66-67). See also the catalogue of Oppitz, No. 844, pp. 612-613.

33 Bischoff, Beiträge zur Geschichte, pp. 335-339.

34 See also Laband, Magdeburger Rechtsquellen, p. 99.

35 Bischoff, "Beiträge zur Geschichte", p. 333,

36 For an overview of passages that overlap in the Wawel Ms and the Magdeburg Bench Law (or Magdeburg's Legal Instructions for Wroctaw of 1295) and at the same time indicate points of departure of the Cracow ms from the Magdeburg Bench Law, see Appendix 3, Nos. 340, 342, 347, 348, 351, 352, 354, 355, 358, 36o, 361, 455, 475 .

37 Carl G. Homeyer, Die Extravaganten des Sachsenspiegels (Berlin, 1861).

38 Emil Kałużniacki, "Die polnische Recension der Magdeburger Urtheile und die einschlägigen deutschen, lateinischen und czechischen Sammlungen", Sitzungsberichte der phil.hist. Classe der Kaiserischer Akademie der Wissenschaften 111 (1886), 157, Note 1. 
TABLE 4 Comparison of the text of Article 27 in Cracow MS (BJ 169) and the matching passages in Magdeburg's Legal Instructions for Wroctaw of 1261 (1261Wr.), Magdeburg Bench Law (MSR), and Wawel MS (BJ 168)

$\begin{array}{lll}\text { 1261Wr. (following F. Ebel's } & \text { Cracow MS } & \text { Wawel Ms (BJ 168) } \\ \text { edition) } & (\text { BJ 169) } & \end{array}$

... vnde recht vnde vnvorklaget, vnde diesilbe man, die gewundet is, komet zů were vnde wundet ienen wider vnde schriet daz ruochte vmbe den vriede, den her an ime gebrochen hat, vnde ne mach her doch vůr gerichte nicht komen vnde klagen van vnkraft sines libes oder von angeste sines libes, vnde komet iene man, die ine erst wundete, mit einer vrevele vore vnde klage: Die ander, an deme die vriede erst gebrochen wart, kome na vnde klage desselben tages in der hanthaften tât ...
... sines libis daz in iener slet odir wundit und shriet he daz gerufte, und kumit iener vor mit der vrevele, und clagit dem richtere, und disser en mac noch en tat vor uncreften sines libis denne nicht vorkumen, und kume dar nach des selbin tages vor, und clage dem richtere und den sheppfen ...
... und der selbe man der gew $[u]$ ndit ist kome czu were und $w[u]$ nde ienin wedir, und schrie das gerufte, umme den vrede den her an im gebrochin hat, und kumt ienir man der in irst hat gew $[\mathbf{u}] \mathbf{n}[\mathrm{di}]$ t mit einim vrevele, und clagit dem richt $[$ er $]$ und desir enmac vor unkreftin sinis libis noch en tat, dennoch nicht vorkomin und kumt dar noch des selbin tagis dar, und clage dem richter und den scheppin ...

a The text in the Wawel MS is a synthesis of $1261 \mathrm{Wr}$. (or MSR, as edited by P. Laband) and the Cracow Ms.

Wawel Ms of a few articles from the Sachsenspiegel. Although the reader is informed about the omission, the compiler fills the gap, apparently with a mind to preserve the numbering sequence of the Cracow Ms, with an equal number of articles before the Jewish oath at the end of the text. ${ }^{39}$ The origin of the partes extravagantes is mixed - two of them mirror the already incorporated provisions of the Magdeburg's Legal Instructions for Wroctaw, another pair have their counterparts in the Sachsenspiegel, while the rest can be matched with passages in the Weichbild vulgate and the Legal Instructions for Zgorzelec (Görlitz) of $1304 .^{40}$ This patchwork combination is not known to exist in any other single text. Apart from the partes extravagantes of the Weichbild, the

39 In print: Bischoff, “Beiträge zur Geschichte”, pp. 354-355.

$40 \quad$ Ibid., p. 345. 
Wawel Ms also contains the partes extravagantes of the Sachsenspiegel published by Carl G. Homeyer (Nos. 31-56). In his commentary, Homeyer stressed their distinctly urban character; some of them have been taken directly from the provisions of the Magdeburg Law. ${ }^{41}$

At this point, it is necessary to consider MS BJ 170a, as it may also have had an impact on the text of the Latin Weichbild. The paper manuscript from the third quarter of the 14 th century contains 175 leaves. ${ }^{42}$ A comprehensive description, more detailed than that in Homeyer's study of the Sachsenspiegel or Władysław Wisłocki's catalogue of manuscripts in the Jagiellonian Library, can be found in Emil Kałużniacki's study of the Magdeburg ortyle. ${ }^{43}$ However, more recently, that description has been superseded by a critical account of MS BJ 170a in a Jagiellonian Library catalogue of medieval manuscripts written by Zofia Włodek and Ilpo Tapani Piirainenen, as well as Winfried Waßer's introduction to their edition of the Sachsenspiegel from that manuscript. ${ }^{44}$ The texts in MS BJ 170a are - without exception - sources of German law. ${ }^{45}$

A careful comparative analysis shows that the provisions of the Magdeburg Weichbild are part of two collations in MS BJ 170a (Cf. the concordance in Appendix 1). While one contains almost exclusively provisions of the Magdeburg Bench Law (MSR), the other complements that collation by an ordered sequence of the Weichbild articles that have not found their way into

41 Homeyer, Extravaganten, p. 236; Laband, Magdeburger Rechtsquellen, p. 100; and Kutrzeba, Historia źródet, p. 205.

42 Art historians have backdated the origin of the manuscript to the first quarter of the 14th century. Cf. Zofia Ameisenowa, Rękopisy i pierwodruki iluminowane BibliotekiJagiellońskiej [Manuscripts and Illuminated Incunabula in the Jagiellonian University Library] (Wrocław - Kraków, 1958), pp. 109-110; and Dariusz Tabor, Malarstwo ksiażkowe na Śląsku w XIV wieku [The Art of Book Illustration in Silesia in the 14th Century] (Kraków, 2008), p. 265.

43 Kałużniacki, "Die polnische Recension", pp. 270-271, Note 1.

44 Wisłocki, Inwentarz, pp. 67-68; Włodek, Catalogus Codicum, pp. 159-162; Oppitz, Deutsche Rechtsbücher, No. 846, p. 614; Ebel and Schelling, Das lateinische lübische Recht, pp. 95-96; and Ilpo Tapani Piirainen, Winfried Waßer, eds., Der Sachsenspiegel aus Oppeln und Krakau, (Schriften der Stiftung Haus Oberschlesien. Landeskundliche Reihe) 10 (Berlin, 1996), pp. 13-15. See also Ilpo Tapani Piirainen, "Der Sachsenspiegel von Conrad von Oppeln und Rechtshandschriften in Breslau", in: Die Anfänge des Schrifttums in Oberschlesien bis zum Frühhumanismus, ed. Gerhard Kosellek, (Tagungsreihe der Stiftung Haus Oberschlesien) 7 (Frankfurt am Main et al., 1997), pp. 241-244.

45 It contains: 1) Indices (regesta) (f. 1-5); 2) Das Landrecht in Latin (k. 6r-47v), 3) Das Lübische Recht (the Lübeck Law in German) (f. 47v-53v); 4) Das Lehnrecht in Latin (f. 54r-78r); 5) an extract from the German Weichbild (f. 8or-87r-Articles 6-18 (the Constitution of Courts); 6) Das Landrecht in German (f. 87r-114r); 7) an extract from the Weichbildchronik about the creation of the world (Weichbildchronik, f. 114r and v); 8) the Weichbild (f. 114v-133v); 9) and Das Lehnrecht in German (f. 133v-158v). 
the MSR. The preparation of the compilations would have been impossible without access to a source other than the Weichbild - in all likelihood, a copy of the Magdeburg Bench Law. There can also be little doubt about the key role of the Cracow Ms, given the identical rubrics in the provisions borrowed first from Magdeburg's Legal Instructions for Wroctaw of 1295 and a characteristic amplification of Article $1 .{ }^{46}$ Taking these clues into account, it can be argued that the Cracow ms was the base of a text (which no longer survives) used later to produce the compilation of MS BJ 170a - probably in Silesia, possibly in Opole. ${ }^{47}$ This scenario cannot be ruled out, even though it envisages the Weichbild being taken back from Małopolska to Silesia. Yet a u-turn of this kind was not without precedent. After all, the Magdeburg ortyle - originally addressed to Cracow - ended up in compilations used outside Małopolska, ${ }^{48}$ and equally, the path of the Weichbild of the Żagań ms was far from straight.

\subsection{The Amplified Weichbild: Baworowscy MS (BN 12607) and the Żagan Ms (II Q 4)}

In his studies of the history of Weichbild, Laband stresses the importance of the bilingual 15th-century Żagań MS (II Q 4) from the Wrocław University Library. However, it is not the only bilingual legal codex produced in the late Middle Ages. Manuscript BN 12607, held by the National Library, also hails from the 15th century and contains an assortment of Magdeburg ortyle in both German and Latin, as well as a bilingual Sachsenspiegel.

In fact, MS BN 126o7, which used to be part of the Baworowscy Collection in Lviv', contains an array of legal texts in addition to the staple rule books the Weichbild and the Sachsenspiegel..$^{49}$ So far, the most accurate list of MS BN 12607 contents has been presented by Friedrich Ebel and Renate Schelling. It is reproduced with minor corrections $s^{50}$ and additional information about the structure of the manuscript in Table 5 .

$46 \quad$ Appendix 3, No. 301.

47 Piirainen and Waßer, Der Sachsenspiegel aus Oppeln, pp. 13 and 27.

48 Laband, Magdeburger Rechstsquellen, pp. 98-99; and Jacob F. Behrend, Die Magdeburger Fragen (Berlin, 1865), p. x.

49 Oppitz's Catalogue, No. 1454, p. 823. Cf. Ebel and Schelling, Das lateinische lübische Recht, p. 102; and Jerzy Kaliszuk and Sławomir Szyller, eds., Inwentarz rękopisów do połowy XVI wieku w zbiorach Biblioteki Narodowej [Inventory of Manuscripts (until the Mid16th Century) in the National Library Collections] (Inwentarze Rękopisów Biblioteki Narodowej) 3 (Warszawa, 2012), pp. 193-194.

The authors make no distinction between the Weichbild and the Sachsenspiegel. 


\section{No. Current folio Notes numbering}
1. $1 \mathrm{r}$
2. $1 \mathrm{~V}$

3. $2 \mathrm{r}-11 \mathrm{~V}$

4. $12 \mathrm{ra}-14 \mathrm{vb}$

5. $15 \mathrm{ra}-26 \mathrm{rb}$

6. $26 v a-26 v b$

7. $27 \mathrm{ra}-61 \mathrm{vb}$

8. $62 \mathrm{ra}-158 \mathrm{vb}$

9. $158 \mathrm{vb}-167 \mathrm{vb}$

10. $168 \mathrm{ra}-217 \mathrm{rb}$

11. $217 \mathrm{rb}-255^{\mathrm{ra}}$

12. $255^{\mathrm{ra}-256 \mathrm{va}}$

13. $256 \mathrm{va}-258 \mathrm{v}$

14. $258 \mathrm{v}$

15. $258 \mathrm{v}-26 \mathrm{ov}$

16. $262 \mathrm{r}-263^{\mathrm{r}}$

17. $263 \mathrm{r}-263 \mathrm{v}$

18. $264 \mathrm{ra}-36 \mathrm{ovb}$ instructions in Polish and German

judgments of the High Court of German Law at the Royal Castle in Cracow

'Oaths of guilds and members of the City Council; some records of the church authorities'a

digest (regesta) of the articles of the Meißen Law

digest (regesta) of the articles of the Weichbild and the

Sachsenspiegel

German ortyl (Urteil) concerning gerada

the Weichbild

the Sachsenspiegel

Magdeburg judgments (ortyle/Urteile)

the Decretum Gratiani

Decretals of Gregory IX, explicit: taken down on 17 June 1437

Digest of the Decretals

the Lübeck Law (das Lübische Recht)

recepta

Treatise on Inheritance and Marriage Law

Joannes Andreae, Lectura arboris consanguinitatis

two cases of consanguinity

Blume des Sachsenspiegels (legal manual)

a Jerzy Kaliszuk and Sławomir Szyller, eds., Inwentarz rękopisów do połowy XVI wieku w zbiorach Biblioteki Narodowej [Inventory of Manuscripts (until the mid-16th Century) in the National Library Collections] (Inwentarze Rękopisów Biblioteki Narodowej) 3 (Warszawa, 2012), p. 193 .

The Baworowscy MS (BN 12607) is a patchwork of texts written in more than one hand. It includes a digest (regesta) of the articles of the Meißen Law, a digest (regesta) of the articles of the Weichbild and the Sachsenspiegel in Latin translation, and a group of texts made up of the Weichbild, the Sachsenspiegel, and the ortyle written by three copyists. According to Ebel and Schelling, the sequence of the ortyle in the Baworowscy ms is nearly identical to their arrangement in the Opatów MS (Oss.) and can be connected with the Cracow 
collection of manuscripts of the Jagiellonian Library Shelfmark 399 (BJ 399). ${ }^{51}$ The composition date of the Weichbild in the Baworowscy Ms is unknown. The explicit on the last leaf of the Decretals of Gregory IX (1437) is not telling in this regard, as it belongs to a different quire than the one with the Weichbild, the Sachsenspiegel, and the ortyle.

The Baworowscy MS is a superb collection, one part of which - namely, a bilingual Weichbild, the Sachsenspiegel, and German-language ortyle - used to function separately as a manuscript of at least 140 leaves. It was then supplemented with a dedicated digest (regesta) written exclusively in German and, successively, with other texts, up to the point at which the manuscript gained its present bulk. One of the most eye-catching items of this collection is a Latin index of the articles of the Weichbild and the Sachsenspiegel. Contrary to the common practice of citing rubrics, it lists with exemplary precision the initial phrase of each article, together with the number of the leaf where it can be found (f. 15ra-26rb). This pagination, which starts with the first Weichbild leaf and ends with the ortyle, is an additional, conspicuous marker of the initially independent functioning of this part of the codex. The index is heavily glossed and cross-referenced: the information about the content of individual articles is compressed into headline phrases. Since this indexing does not cover the ortyle, we may surmise that the glossator did not know German well enough to do the job.

This may also have been a factor in his handling of the Weichbild. He put the Latin text first and had the matching article in the original German follow it. There are, however, some inconsistencies: for example, Article 3 is missing from the German text. That may have been caused by the copyist's error: he divided Article 2 into two and placed those parts after the Latin Articles 2 and 3. Another irregularity can be found around Article 48. The copyist added to it a Latin translation of the relevant Magdeburg ortyl and left some room below for the original German text. However, instead of then filling that gap, he decided to refer the reader to Folio XXI (f. 47v). There, in an annex to Article 74, we do find a German ortyl concerning inheritance, but it is hardly pertinent to the matter in hand (Article 48 is about inheritance law). Moreover, the Latin translation of the ortyl attached to Article 74 matches the adjacent German text, but differs from the Latin text appended to Article 48. Yet another editorial

$51 \quad$ Friedrich Ebel, "Nachträge zu Homeyer - Borchling - Gierke - Eckhardt: Die deutschen Rechtsbücher des Mittelalters und ihre Handschriften", Zeitschrift der Savigny-Stiftung für Rechtsgeschichte. Germanistische Abteilung 99 (1982), 312; Ebel and Schelling, Das lateinische lübische Recht, p. 102, Note 26. 
intervention made for no apparent reason is the shortening of Article 9o in the German text. ${ }^{52}$ At no point, however, can there be any doubt that the Latin text was the author's (or rather, the copyist's) primary concern and that he took great care to preserve its integrity. If his preference for Latin is taken as an indication of the manuscript's provenance, Poland under the Jagellons rather than Silesia is a more fitting place of origin. At the same time, the omissions suggest that the compiler (copyist) of the manuscript could not have been the author of the Latin translation of the ortyle annexed to the Weichbild.

The Żagań (Sagan) MS is a massive codex of 539 leaves. It is made up of several parts which are dated back to the $15^{\text {th }}$ century. ${ }^{53}$ The first such part, which is of particular interest to this study, is written in a rather careless cursive hand and is the work of one scribe (f. 1-134). The uniform hand and its distinct foliation are clear indications that it used to function separately from the rest of the codex. What has also attracted attention is the arrangement of its constituent texts. Laband was the first to note that the three key texts of the Saxon-Magdeburg Law appear in this manuscript in the same order as in Łaski's Statutes. ${ }^{54}$ Under the heading Liber I, the collection opens with the Weichbild (f. 1r-36r), immediately followed on the verso of the first quire by the Landrecht from the Sachsenspiegel (f. $36 \mathrm{v}-95 \mathrm{v}$ ). The third section, the Lehnrecht from the Sachsenspiegel (f. 98r-125v), is separated from the Landrecht by two short texts, 'Von der Herren Geburt' (f. 96) and the Weichbildchronik, detached from the text of the Weichbild itself (f. 96-97). These are followed by Pope Gregory XI's bull Salvator humani generis and an alphabetical subject index. It is worth noting that other monuments of German law, like the Meißen Law and the Sachsenspiegel (regesta), can be found in other parts of the Żagań ms.

The author of the first part of the Żagań Ms arranged the Latin and German text of the Weichbild in parallel, giving the Latin version pride of place. The German articles are often curtailed or even left out. In the whole manuscript, there is only one instance of a German text standing alone. This error of omission is most likely due to inattention on the part of the copyist (Article 9 with a Magdeburg ortyl attachment; in this section, article numbering is according to Żagań Ms), but it can also serve as proof that the compiler of the Żagań Weichbild Ms was not the translator of the attached ortyle. Moreover, in a number of cases, he made considerable alterations to the German text. Some articles are omitted (Articles 72, 73, 78, and 79, following the MS Gn. pagination); some are excerpted (Articles 1, 66, and 107); and a significant number of

52 Cf. Appendix 2, No. 193.

53 In Oppitz's Catalogue, No. 268, pp. 411-413.

54 Laband, Magdeburger Rechtsquellen, pp. 96-98. 
them appear in the manuscript in a severely curtailed form (Articles 2, 4, 6, 14, $33,70,75,76,83,86,88,90,91,93,97,100,103$, and 105$).{ }^{55}$ Occasionally, important details do not match up (Articles 14, 26, 28, and 106). More often, there are minor differences between the German and the Latin texts, such as, for example, the addition of Daz selbe hat der man seyn teil dem, derym ebin burtig ist in Article 28. The phrase neither occurs in the Latin translation nor in other German texts (see Nr. 342 in Appendix 3). Another notable feature of this part of the Żagan MS is the composition of the rubrics. The German rubrics seem to have been in place first, while the Latin ones have the appearance of being filled in later (and the job has not been completed). The primacy of Latin in Part I of the Żagan ms is a strong indication that its place of origin should be sought outside Silesia - probably in Małopolska, but possibly in Cracow. If this conjecture is allowed to stand, the follow-up argument is incontrovertible: the manuscript must have been brought to Silesia and eventually deposited at the Augustinian Abbey Library at Żagań.

At any rate, there can be no doubt about the features that the two manuscripts (Baworowscy, BN 12607 and Żagań MS II Q 4) have in common - that is, parallel arrangement of the Latin and the German text, the primacy of Latin, and the use of the ortyle in conjunction with the articles of the Saxon-Magdeburg Law. Laband notes that the arrangement of the texts in the Żagan Ms is identical to that of the Cracow Ms, and for the difference in the number of articles, Laband offers the explanation that the compiler of latter simply divided one of them into three (cf. the Concordance Table in Appendix 1). He also points out that the Latin articles are glossed with notes that reappear in Łaski's Statutes, although not all of the alterations acknowledged in the latter can be found in the Żagań Ms. These observations led him to formulate a thoroughly justified conjecture that the Żagań Ms was an intermediary between the so-called Konrad of Opole's compilation and Łaski's Statutes. Laband has no problems with explaining the origin of some of the supplementary material in the Żagan MS and the statutes - it comes from collections of Magdeburg judgments (ortyle), like the Dresden or the Torun ms. Moreover, nearly all of them can be found in the Magdeburger Fragen and certain other manuscripts. In fact, only one of them is missing from the German-language collection of ortyle in MS BJ $399 .{ }^{56}$ Laband reiterates Jacob Friedrich Behrend's argument that

55 For example, the following passage is missing from the German counterpart of Article 88:... quod facere potest incontinenti si vult, aut per sex ebdomadas in iudicio sculteti. Sin autem vir iuramentum unica manu prestare debet, quod in eodem oportet facere iudicio. 
all those collections contain ortyle addressed to $\mathrm{Cracow}^{57}$ and concludes that they all stem from the Cracow collection of the Magdeburg judgments. This would mean, in effect, that the Weichbild was augmented with ortyle from that very collection. ${ }^{58}$

This also means that further studies of the Latin manuscripts of the SaxonMagdeburg Law have to address the following questions: 1) does the German text of the Weichbild in Baworowscy and Żagan manuscripts stem from the Cracow ms? 2) Can Laband and Behrend's argument about the origin of the ortyle attached to the Weichbild be corroborated by more precise evidence? 3) What are the reasons for the augmentation of the Weichbild, and what were the circumstances in which the augmentation took place?

\subsubsection{Problems of Filiation of the Cracow MS}

The Weichbild in the Baworowscy Ms (BN 12607) is fairly close to the text in the Cracow MS (BJ 169). However, the extensive alterations in the German text of the Żagan MS (II Q 4) render comparisons with other sources extremely difficult. Nevertheless, it is possible to identify passages in which a characteristic feature of the Cracow MS is mirrored by the Żagań MS and Baworowscy MS (exclusively). One such example is provided by a phrase from Article 22 of the Cracow ms (for an in-depth comparison, see Table 6).

Moreover, in none but these three manuscripts (Cracow Ms, Baworowscy MS and Żagań MS) does the text of Article $88^{59}$ leave out the exemplification of the offence, that is, insulting a member of the jury (the Bench). ${ }^{60}$ Article $80^{61}$ about the Burggrafs judicial powers leaves out the wording of the original source, which mentions exclusively the Burggraf of Magdeburg. ${ }^{62}$ Manuscripts BJ 169 and BN 12607 also share a passage about the aldermen's right to convoke an assembly (burding): "Di ratman legen ir burtdinc uz swenne so si wellen mit der wizzegisten rate". This is a highly significant addition to the original German text; its counterpart can be found solely in the corresponding Latin texts. ${ }^{63}$

These examples show that the Cracow Ms indeed influenced the Żagan and the Baworowscy manuscripts, although it was not alone in that role. The impact of other sources is manifested in the numerous differences between the

\footnotetext{
57 Behrend, Die Magdeburger Fragen, pp. X-XI.

$5^{8}$ Laband, Magdeburger Rechtsquellen, p. 99.

59 Numbering of MS BJ 169.

6o Cf. Appendix 3, No. 475 .

$61 \quad$ Numbering of MS BJ 169.

62 Cf. ibid., nr 455 .

63 Due to the thorough revision of Article 1 in the Żagan ms, that text cannot be included in this comparison.
} 
TABLE 6 Comparison of Article 22 with matching phrases in German manuscripts. Numbering of articles follows the MS BJ 169

\begin{tabular}{|c|c|c|c|c|c|c|}
\hline $\begin{array}{l}\text { Legal } \\
\text { Instructions } \\
\text { for Wroctaw } \\
\text { of } 1261\end{array}$ & $\begin{array}{l}\text { Cracow MS } \\
\text { BJ } 169\end{array}$ & $\begin{array}{l}\text { Baworowscy } \\
\text { MS BN 12607 }\end{array}$ & $\begin{array}{l}\text { Żagań MS II } \\
\text { Q }_{4}\end{array}$ & $\begin{array}{l}\text { Henryków } \\
\text { MS II F } 8\end{array}$ & BJ $170 a$ & $\begin{array}{l}\text { Wawel } \\
\text { MS BJ } 168\end{array}$ \\
\hline $\begin{array}{l}{\left[3^{2}\right] \text { Swer }} \\
\text { so einen } \\
\text { schephenen } \\
\text { beschildet } \\
\text { uf der banc, } \\
\text { her gewinnet } \\
\text { sine bůze, } \\
\text { drizich } \\
\text { schillinge, } \\
\text { vnde die } \\
\text { richtere sin } \\
\text { gewette. }\end{array}$ & $\begin{array}{l}{[22] \text { Swer }} \\
\text { so einen } \\
\text { scheppfen } \\
\text { shildit uf } \\
\text { der banc, } \\
\text { der muz } \\
\text { dem selbin } \\
\text { sheppfen } \\
\text { buze geben } \\
\text { drizic } \\
\text { shillinge und } \\
\text { der richter } \\
\text { gewinnet sin } \\
\text { gewette. }\end{array}$ & $\begin{array}{l}{[28] \text { Wer }} \\
\text { so einen } \\
\text { scheppen } \\
\text { schildet off } \\
\text { der banc, } \\
\text { der muß } \\
\text { dem salbin } \\
\text { scheppin } \\
\text { busse geben } \\
\text { dreizig } \\
\text { schillinge und } \\
\text { der richter } \\
\text { gewinnet sein } \\
\text { gewette. }\end{array}$ & $\begin{array}{l}{[24] \text { in initio. }} \\
\text { Wer einen } \\
\text { schildet off } \\
\text { der banck, } \\
\text { der muß } \\
\text { dem selbigen } \\
\text { scheppen } \\
\text { busse } \\
\text { gaben xxx } \\
\text { schilli[n]g[e] } \\
\text { undderrichter } \\
\text { gewynet } \\
\text { seyn gewette. }\end{array}$ & $\begin{array}{l}\text { [22] Wer } \\
\text { so eynen } \\
\text { scheppen } \\
\text { schildet uff } \\
\text { der bank, } \\
\text { der scheppe } \\
\text { gewynnet } \\
\text { seyne busse } \\
\text { dreisig } \\
\text { Schillinge } \\
\text { und der } \\
\text { Richter sein } \\
\text { gewette. }\end{array}$ & $\begin{array}{l}\text { xx. Swer } \\
\text { so einen } \\
\text { scheppen } \\
\text { beschildet } \\
\text { uf der } \\
\text { bank, der } \\
\text { gewinnet } \\
\text { sine buze } \\
\text { drizic } \\
\text { schillinge, } \\
\text { und der } \\
\text { richter sin } \\
\text { gewette. }\end{array}$ & $\begin{array}{l}{[24] \text { in }} \\
\text { initio. Swer } \\
\text { so einin } \\
\text { scheppin } \\
\text { beschildit } \\
\text { uf der } \\
\text { banc, } h[\text { er] } \\
\text { gewinnit } \\
\text { sine buse } \\
\text { drisic } \\
\text { schillinge } \\
\text { und der } \\
\text { richter sin } \\
\text { gewette. }\end{array}$ \\
\hline
\end{tabular}

Cracow Ms and the text of the other two manuscripts. Not all the alterations in 'junior' texts are due to borrowing - many of them could well have been corrections and revisions that are part of a natural evolution of a text. Nevertheless, there are passages in the latter that can be traced to the old sources of the Weichbild, the Magdeburg Bench Law, and the Henryków ms. The Henryków MS is independent of the Cracow MS, although they both have a common base. Two examples of such an alternate affiliation are listed in the concordance in Appendix $3 .{ }^{64}$ They show up against the backdrop of omissions in the Cracow Ms, probably caused by scribal error. Although the slips are quite inconspicuous, they are not copied. The fact that the correct version appears both in the Baworowscy MS and the Żagań MS 4 is clear sign that these manuscripts rely on a source that is closer to the Weichbild prototype than the Cracow Ms. That prototype must have functioned in the territory of the Kingdom of Poland by the middle of the 14th century at the latest, or otherwise the defects of the

64 Cf. Appendix 3, Nos. 348 and 355 . 
Cracow MS would have left their mark on the Latin Weichbild. In other words, the Cracow Ms could not have been the sole base of the Latin translation of the Weichbild. The evidence examined here provides proof of the indebtedness of both the Baworowscy MS and the Żagań Ms to the Cracow Ms; it also points to the functioning in early 14th-century Poland of another German text, independent of and closer to the 'original' Weichbild than the Cracow Ms.

\subsubsection{Provenance of the Supplements}

The key role in establishing the provenance of the ortyle is played by Article 14 of the Weichbild, which concerns itself with the material circumstances of wives and widows. ${ }^{65}$ It is supplemented with two ortyle, one after the otheran arrangement which is by no means insignificant. Laband's research demonstrates that the same pair of judgments appear in the Dresden and the Torun manuscripts, ${ }^{66}$ whereas the second ortyl is absent from all other texts except MS BJ 399. The latter manuscript, however, could not have been the source of the augmentation, because it does not feature the first of the two texts. One way to solve this riddle would be go through non-systematic collections of ortyle, as well as those that are included in Jacob F. Behrend's Die Magdeburger Fragen, and check them for the presence of the 'control pair'.

While Old Chełmno Law had to be ruled out as a likely source, ${ }^{67}$ the two ortyle did appear in some other manuscripts. One such manuscript is the Poznań Book of Magdeburg and Meißen Law (in German), edited and published by Witold Maisel. ${ }^{68}$ Another is the Latin translation of the collection of the ortyle in the Żegota Pauli's Ms (BJ 4405). ${ }^{69}$ However, the translation does not match the text of the ortyle in the Latin Weichbild. It is therefore impossible that the compiler of the Weichbild took advantage of that earlier Latin translation. What can also be said with great certainty is that the Żegota Pauli's Ms is closely associated with Cracow, and it is highly likely that both the translation of the ortyle's collection as well as the writing of this manuscript took place in

65 Cf. Appendix 2, No. 44.

66 Laband, Magdeburger Rechtsquellen, p. 99. The collection of texts from the Dresden MS was published by Wasserschleben, Sammlung, pp. 80-120.

67 The Chełmno Law can offer hardly any material to supplement the text of the Weichbild. I have reached this conclusion after consulting the 1838 German edition of Der Alte Kulm: Karl Ch. Leman, ed., Das Alte Kulmische Recht, mit einem Wörterbuche (Berlin, 1838); and the Polish translation from 1985: Witold Maisel and Zbigniew Zdrójkowski, eds., Andrzej Bzdęga and Anna Gaca, trans., Prawo starochetmińskie 1584 (1394), (Teksty Pomników Prawa Chełmińskiego w Przekładach Polskich) 2 (Torun, 1985), p. 8.

68 Witold Maisel, ed., Poznańska księga prawa magdeburskiego i miśnieńskiego [The Poznań Book of Magdeburg-Meißen Law] (Wrocław, 1964), IV.15o and 151, pp. 144-145.

69 See Chapter 1.3.14. 
Cracow. ${ }^{70}$ But the base of the ortyle's translation in the Żegota Pauli's Ms could not be MS BJ 399. Yet in spite of indisputable similarities, noted by Stanisław Estreicher, ${ }^{71}$ the two manuscripts differ considerably. One of the differences is the lack in MS BJ 399 of the second of the two 'control' ortyle. Yet it could not be a redaction of German ortyle that is annexed to the Baworowscy MS at the back of the Sachsenspiegel, because it has none of the supplements that we find in the Weichbild. In effect, we have to assume the existence of another base text, possibly a prototype of the Pilzno Codex of German-language ortyle, edited by Władysław Wisłocki. That collection contains both 'control' ortyle (Articles cxxxxv and cxxxxvi, numbering in Wisłocki's edition). ${ }^{72}$ It can be taken for granted that Pilzno received its collection of ortyle from Cracow. It should be noted that all the ortyle attached to the Weichbild are included in the earliest Polish translation of ortyle published by Józef Reczek and Wacław Twardzik. This Polish translation follows the arrangement of the Latin translation of the ortyle in the Żegota Pauli's Ms, ${ }^{73}$ which also includes all the ortyle from the Weichbild.

As a conclusion, it can be assumed that the ortyle in the Weichbild came from the German-language collection associated with Cracow, which could be the base for the German-language Pilzno Codex and for the oldest Polish translation. This collection was also close to the Latin collection of ortyle in MS BJ 4405. In all, a complete list of ortyle incorporated into the Weichbild includes - in addition to those identified by Laband, that is, the ortyle annexed to Articles 7, 14, 48, 68, 73, 74, 90, 95, and 97 of the Weichbild (numbers following the Gniezno Ms, see Chapter 1.3.1. $)^{74}$ - those ortyle that are supplemented to Articles $4,9,13,48,58,9$ o, and $105^{75}$ In this way, Laband's broad conjecture that the augmentation of the Weichbild is connected with the creation of collections of Magdeburg ortyle in Cracow is proven correct.

$70 \quad$ See Stanisław Estreicher, "Nieznane teksty ortyli magdeburskich" [Recently Discovered Texts of the Magdeburg ortyle], in: Studia staropolskie. Ksiegga ku czci Aleksandra Brücknera [Old Polish Studies: A Festschrift in Honour of Aleksander Brückner] (Kraków, 1928), passim.

71 Estreicher, "Nieznane teksty", p. 121. It is also worth noting that the compiler of this Weichbild did not use the Latin translation of the ortyle, known from the Działyńscy Codex I and based on a shorter German-language collection, which has been preserved in MS BJ $17 \mathrm{Ob}$.

72 Władysław Wisłocki, "Kodeks pilzneński ortylów magdeburskich" [The Pilzno Codex of Magdeburg ortyle], Rozprawy Akademii Umiejętności 2 (1874), 159.

73 Józef Reczek and Wacław Twardzik, Najstarsze staropolskie ttumaczenie ortyli magdeburskich [The Earliest Polish Translation of the Magdeburg ortyle] 1 (Warszawa, 1970), p. 18.

74 Appendix 2, Nos. 24, 44, 107, 158, 163, 165, 198.

75 Appendix 2, Nos.15, 29, 30, 38, 142, 193, 200, 217. 
The Reasons and Circumstances of the Augmentation of the Weichbild with Sample ortyle

Before we answer the question of why a law code like the Weichbild came to be augmented with supplementary material (ortyle), it is worth taking a closer look at the thematic range of this innovation. As it happens, some provisions seem to be more susceptible to augmentation than others. Such provisions are those that are concerned with: surety in cases of killing and wounding (Article 7); the legal status of guests (aliens) (Article 9); pledge (Article 13); dower (Article 14); representation of heritable grandchildren (Article 48); time limits in oath taking (Article 68); inheritance rules (Article 73); duty of care (Article 74); aldermen's court (Article 9o); inheritance of goods hidden away from the taxman (Article 95); and dropping charges (Article 97) ${ }^{76}$ It is no accident that most of those situations were regarded as key issues in the administration of justice and were subject to regulations in 14th-century municipal by-laws (wilkierze, Ger. Willküren) and royal privileges for Cracow. ${ }^{77}$ As the ortyle appeared at those points where such problems were addressed, it is only reasonable to assume that the augmentation of the Weichbild was driven by pragmatic concerns.

The time at which the augmentation occurred is unknown. We do not even know whether the ortyle were attached first to the German or the Latin text, or whether it happened simultaneously. Apart from Łaski's Commune incliti, there are five extant Weichbild texts augmented with Magdeburg ortyle, three of which are only in Latin (two of them in Latin and German). The circumstances in which the process of expanding the Weichbild began are very difficult to make out, as there is no manuscript with an unalloyed body of an augmented German text. Yet, the fact that we do not have such a source is no

76 Laband, Magdeburger Rechtsquellen, p. 98; and Bischoff, "Beiträge zur Geschichte", pp. 36o-362. Cf. the following records in Appendix 2: cf. supra notes 73 and 74. Numbers of articles according to the Ms $\mathrm{Gn}$.

77 Michał Patkaniowski, Krakowska rada miejska w średnich wiekach [The Cracow City Council in the Middle Ages] (Kraków, 1934), pp. 42-46 and Chapter 9 (Legislative Functions of the Cracow City Council); Marcin Starzyński, Krakowska rada miejska w średniowieczu [The Cracow City Council in the Middle Ages] (Kraków, 2010), pp. 100-120 and Appendix 2 "Medieval by-laws (wilkierze) of the City of Cracow"; Maciej Mikuła, Prawodawstwo króla i sejmu dla matopolskich miast królewskich (1386-1572). Studium z dziejów rzadów prawa w Polsce [Royal and Parliamentary Legislation for the Royal Towns of Małopolska (1386-1572): A Study in the History of the Rule of Law in Poland] (Kraków, 2014), passim; and Maciej Mikuła, "Statuty prawa spadkowego w miastach polskich prawa magdeburskiego (do końca XVI wieku)" [Inheritance Statutes in Polish Towns under Magdeburg Law (until the End of the 16th Century)], Z Dziejów Prawa 7 (15) (2014), 33-63. 
proof of it never having existed. At any rate, this situation leaves us in the realm of speculation and hypotheticals.

The augmentation of the Latin text could have been done by juxtaposing the German text - already supplemented with ortyle - and the Latin Weichbild, as had happened in the case of the Baworowscy and the Żagań manuscripts. Another possible scenario would have the augmentation take place simultaneously. The author had at hand both the German and the Latin Weichbild, put matching portions of either text next to each other, and attached to some of them the appropriate ortyle, which he had to translate into Latin. Although we know of no extant German-language manuscript with an augmented text, its existence cannot be ruled out. A third scenario in which the ortyle would have been initially attached to the Latin text is utterly implausible for one simple reason: the Latin translations of the collections of ortyle in the Żegota Pauli's MS and in the Działyńscy Codex I do not fit the adjacent passages in the Weichbild. In short, they could not have been used to supplement the text of Ius municipale Magdeburgense. For the third scenario to work, one person would have to translate the German ortyle into Latin and attach them to the Latin Weichbild, and then another person would have to go through the whole body of text again to adjust its Latin and German parts, to find the right German-language ortyle and fit them in the German-language Weichbild. This is too complicated and frankly, does not make a great deal of sense.

Both the tracing of the origin of the ortyle to an unknown Cracow collection and the fact of their being attached to a German-language Weichbild associated with the Cracow City Council manuscript give weight to the conjecture that Cracow was the place where the augmentation of the Weichbild began. Let me also note that if an interest in a practice-oriented German law book was limited to just a few bigger Polish towns, in that circle, Cracow would be the most likely sponsor of such an ambitious initiative.

\subsection{Summary: Evolution of the German Text and the Problem of Adaptation of the Magdeburg Law in the Kingdom of Poland}

Let me now recapitulate the main points of the argument. The German Weichbild representative of the Silesian-Małopolska compilation was produced in Silesia in 1295-1308. The earliest extant text in the manuscript is not identical to the archetype which was the base of both the Cracow and the Henryków manuscripts. Patterns of filiation link the Cracow ms to the next generation of German texts, like the extant Wawel MS, MS BJ 170a, the Baworowscy Ms, and the Żagań Ms. At some point, one of those texts was augmented with a selection of Magdeburg judgments from a collection of ortyle created in Cracow. These judgments were also translated into Latin and added 
to the Latin Weichbild. The circumstances of this momentous development remain obscure. Of the various scenarios, only one can be definitely ruled out, namely, that the Latin Weichbild was the first to be augmented, and the German Weichbild followed suit.

Although the dynamics of the German-language texts of the SilesianMałopolska compilation were driven by the inclusion of selected Magdeburg ortyle, which most likely took place in Cracow, the main axis of the evolution remained in the area of Latin texts. The following sections of this chapter will analyse those texts, offering not only a detailed description of their characteristics, but also trying to deduce who may have used them.

\section{Latin Manuscripts and Jan Łaski's Printed Text}

Studies of manuscripts with Latin texts of the Magdeburg Weichbild began more than 15 o years ago, and their number has been growing steadily. Most of research effort is focused on in-depth analyses of the sources and the creation of new descriptive catalogues. I have relied primarily on a catalogue of manuscripts of German law compiled by Ulrich-Dieter Oppitz. Nearly all of the manuscripts discussed here are listed either in Oppitz's main work or its supplements. The two items that are outside the scope of Oppitz's catalogue are MS RK 45/28 from the Library of the Catholic Seminary at Kielce ${ }^{78}$ and MS воz 90 from the National Library in Warsaw. ${ }^{79}$ In the course of my research, I have built a database of 18 manuscripts, with 19 copies of the Silesian-Małopolska Weichbild, one digest (regesta) from the Pleszew City Council Records published by Witold Maisel, and one printed text: Jan Łaski's Commune incliti. Unfortunately, a significant number of manuscripts were destroyed during the Second World War, especially in 1944, during the suppression of the Warsaw Rising (the losses are duly acknowledged in Oppitz's catalogue).$^{80}$ One important source, the Sanok

${ }_{7} 8$ Jerzy Wolny, "Inventaire des manuscrits théologiques médiévaux de la bibliothéque du chapitre à Kielce", Mediaevalia Philosophica Polonorum 16 (1971), 43-85; Maciej Mikuła, "Das sächsisch-magdeburgische Recht in den Manuskripten der Bibliothek des Priesterseminars in Kielce, Signatur RK 45/28 - Ergänzung zu Deutsche Rechtsbücher des Mittelalters", Zeitschrift der Savigny-Stiftung für Rechtsgeschichte: Germanistische Abteilung 1/137 (2020), 505-510.

79 Kaliszuk and Szyller, Inwentarz rękopisów, p. $5^{2}$.

8o Some of the lost manuscripts from the National Library collection are listed in Oppitz's Catalogue. Cf. records 1463, 1466, 1470, 1472, 1473 and 1480. Monographic studies: Jerzy Kaliszuk, Codices deperditi. Średniowieczne rękopisy tacińskie Biblioteki Narodowej utracone w czasie II wojny światowej, [Codices deperditi: Medieval Latin Manuscripts of the National Library Lost during World War II], Vol. 1: Dzieje i charakterystyka kolekcji 
Ms, has vanished without trace. However, as a fairly detailed description of its contents can be found in the Proceedings of the Academy of Sciences in Vienna from the year 1886, I have decided to include that manuscript in my overview.

\subsection{Gniezno Ms (1359) in the Archdiocesan Archives of Gniezno, Gn. $104^{81}$}

The Gniezno Ms is one of the documents analysed closely by Zygfryd Rymaszewski in his studies of the Sachsenspiegel. ${ }^{82}$ Dated 1359, it is a fairly close copy of Konrad of Sandomierz's autograph, though not identical to it (see below in this section). It is the work of scribe the Mikołaj of Cieszyn, who makes it explicitly clear (on three occasions) that this translation of the Magdeburg Law from German into Latin was conducted by Konrad of Sandomierz at the request of Mikołaj of Pacanów, a burgher of Sandomierz. A meticulous description of the manuscript by Stanisław Estreicher can be found in Father Tadeusz Trzciński's catalogue of medieval manuscripts in the Chapter Library at Gniezno. ${ }^{83}$ The manuscript is written in a neat hand in two columns. The articles are headed by rubrics in red and numbers. In his account of the contents of this manuscript, Stanisław Estreicher lists seven items. The volume begins with an incipit to Iuris provincialis (Sachenspiegel, f. 1-2v), followed by the Prologue and the main text of the Latin Sachsenspiegel - versio Sandomiriensis (up to f. 8ov). The next four items in Estreicher's description are in fact constituent parts of the Magdeburg Weichbild: the incipit to Ius

[A History and Description of the Collection] (Wrocław, 2016), p. 105, 192 and 520; 2.2: Katalog rękopisów utraconych [A Catalogue of the Lost Manuscripts] (Wrocław, 2016), No 1153, 1207 [series: Dziedzictwo Kulturowe po Skasowanych Klasztorach (Cultural Heritage of the Dissolved Monasteries), ed. Marek Derwich, 8/1, 8/2.2]. See also Alexander Rogatchevski's account of his search for the lost manuscripts of the Saxon-Magdeburg Law in the archives and libraries of St Petersburg: Alexander Rogatchevski, "Das sächsischmagdeburgische Rechtsdenkmäler und verwandte Quellen in den St. Petersburger Handschriftensammlungen", in: Grundlagen für ein neues Europa. Das Magdeburger und Lübecker Recht in Spätmittelalter und Früher Neuzeit, eds. Heiner Lück, Matthias Puhle, and Andreas Ranft, Quellen und Forschungen zur Geschichte Sachsen-Anhalts, 6 (Köln Weimar - Wien, 2009), pp. 268-269.

81 Hereafter referred to as Gn.; Oppitz, Deutsche Rechtsbücher, No. 573 .

82 Rymaszewski, Łacińskie teksty Landrechtu Zwierciadta Saskiego w Polsce. Versio, pp. 76-77; and Oppitz, Deutsche Rechtsbücher, No. 573.

83 [Tadeusz] Trzciński, Średniowieczne rękopisy biblioteki kapitulnej w Gnieźnie [Medieval Manuscripts in the Cathedral Chapter Library at Gniezno], (Rocznik Towarzystwa Przyjaciół Nauk Poznańskiego) 35 (Poznań, 1909), pp. 307-310. The manuscript is mentioned in Jadwiga Rył, "Biblioteka katedralna w Gnieźnie" [Cathedral Chapter Library at Gniezno], Archiwa, Biblioteki i Muzea Kościelne 33 (1976), 278; and Jadwiga Rył, "Biblioteka katedralna w Gnieźnie. Aneks” [Cathedral Chapter Library at Gniezno. Appendix], Archiwa, Biblioteki i Muzea Kościelne 36 (1978), 238. 
municipale (f. $82 \mathrm{r}-283 \mathrm{v})$; articles of the Weichbild $(83 \mathrm{v}-115 \mathrm{v})$; the Jewish oath added to the Weichbild (f. 115v-116); and a fragment about the Constitution of Courts (f. 116v-121r), separated by explicit - the ending of the Book of Magdeburg Law (f. 116v). The whole text ends with Conclusio libri, which again mentions Konrad of Sandomierz. The scribe Mikołaj of Cieszyn added in the date on which he completed his writing, marked as the vigil of the Feast of the Holy Trinity A.D. 1359 (f. 121r-121v). This collection contains exclusively texts of urban law.

So far, the Weichbild in this manuscript has not been the subject of indepth analysis. The need for such research was voiced by Laband. ${ }^{84}$ Zygfryd Rymaszewski mentioned the Gniezno Ms several times in his study of the Sachsenspiegel. ${ }^{85}$ Some of its provisions dealing with issues of private law have been analysed in two recent articles. ${ }^{86}$ As the earliest extant text of legal interest, it provides an important point of reference for other Latin sources. Its main text is glossed in what looks like 15th-century hand; the glosses are scant but not insignificant. Their presence indicates that the text of the Gniezno MS it is not identical to Konrad of Sandomierz's archetype. As has been recently observed, it is only in this manuscript and in the Działyńscy Codex I (MS Dział. I) that the text of Article 24 does not contain certain phrases which clarify the meaning of the provision concerning the validity of claims made by servants for payment for performance of services. ${ }^{87}$ Moreover, in most texts, except MS Gn. and Ms Dział. I, Articles 79 and 105 require the proof of the oath of one rather than seven individuals in claims regarding debt payment. A commentator on the Działyńscy Codex I amended that gloss, as did a user of the Gniezno Ms (who added in the correct number of compurgators). This variant is peculiar to the two manuscripts, and it does not occur in other German texts. ${ }^{88}$ It

84 Paul Laband, "Eine bisher unbekannte Rechtshandschrift", Zeitschrift der Rechtsgeschichte 11 (1873), pp. 50-51.

85 Rymaszewski, Lacińskie teksty Landrechtu Zwierciadta Saskiego w Polsce. Versio, esp. Table 6, p. 222.

86 Maciej Mikuła, "Modyfikacje łacińskich tekstów Weichbildu magdeburskiego a ewolucja prawa w średniowiecznych miastach polskich. Uwagi wstępne" [Modifications of Latin Texts of the Magdeburg Weichbild and the Evolution of Law in Medieval Polish Towns: An Introduction], in: Acta Iuridico-Historica Pilsnensia, 2012-2013 (published 2014; ed. Vilém Knoll), pp. 142-147; and Maciej Mikuła, "Die Modifizierung des Erb- und Familienrechts im Magdeburger Weichbildrecht (Einführung zum Thema)", in: Judiciary and Society Between Privacy and Publicity, ed. Danuta Janicka, 8th Conference on Legal History in the Baltic Sea Area, 3rd-6th September (Torun, 2015), pp. 336-342.

87 Records 6o, 174, and 216 in Appendix 2.

88 Rekords 341, 453, and 501 in Appendix 3. 
was probably the copyist Mikołaj of Cieszyn who changed the wording of a faithful Latin translation of the German text (see Chapter 2.4.3.).

\subsection{St Petersburg Ms (1367-1368) in the Library of the Russian Academy of Sciences in St Petersburg, F $143^{89}$}

The second earliest text of the Weichbild is part of MS F 143, dated 1367-1368. Its description can be found in a number of catalogues; ${ }^{90}$ Laband included it in his preliminary analysis of landmark texts of German law. ${ }^{91}$ In his earlier studies, of the Weichbild Laband made use of German texts and three Latin texts supplemented with ortyle (Opatów Ms, Żagań Ms, and Łaski's Statutes). After discovering MS F 143, he located its Weichbild in between the Cracow MS 169 and the complete text in Jan Łaski's Statutes. ${ }^{92}$

In its present form, the St Petersburg MS is a composite of two separate manuscripts, as shown by the collation of quires, the change of hand, and the size of margins. The first part contains a German-language Sachsenspiegel, copied by Franczek Lemberk from Lviv' and completed by 22 June 1367 (f. $1 \mathrm{r}-126 \mathrm{v}$ ). The Sachsenspiegel Landrecht and Lehnrecht are preceded by rubric indices. Work on the Sachsenspiegel must have taken a long time, since the copying of Book II was not finished until 6 December 1367. The second part of the codex consists of two quires of 12 leaves each. It is written in a different hand, and the writing is very dense and fills all the available space on the page. The different origins of the two parts are indicated in a most conspicuous manner by the width of their margins. For example in Part One, folium 61 - with the first page of Book III of the Sachsenspiegel - the width of the left margin is in the range of 4.4-4.7 mm, the right margin $(3.8-4.3 \mathrm{~mm})$, the upper margin $(3.4-3.8 \mathrm{~mm})$, and the lower margin $(5.2-5.3 \mathrm{~mm})$; the irregularities are the effect of uneven edge cuts. Folium $127 \mathrm{r}$ with the first page of the Weichbild has narrower margins - the left margin $-3.2-3.4 \mathrm{~mm}$; the right margin $-2.5^{-2.7} \mathrm{~mm}$; the upper margin $-2.4-2.5 \mathrm{~mm}$, and the lower margin - 4.9-5.1 $\mathrm{mm}$. It is written in a neat hand, even though the script is small and dense. Each article, excepting

$89 \quad$ Hereafter referred to as $\mathrm{F} 143$.

$90 \quad$ Oppitz, Deutsche Rechtsbücher, No. 931, pp. 647-648; Oppitz, "Ergänzungen zu Deutsche Rechtsbücher des Mittelalters und ihre Handschriften", Zeitschrift der Savigny-Stiftung für Rechtsgeschichte: Germanistische Abteilung 128 (2011), 448; and Alexander Rogatchevski, "Die sächsisch-magdeburgische Rechtsdenkmäler und verwandte Quellen in den St. Petersburger Handschriftensammlungen", in: Grundlagen für ein neues Europa. Das Magdeburger und Lübecker Recht in Spätmittelalter und Früher Neuzeit, eds. Heiner Lück, Matthias Puhle, and Andreas Ranft, Quellen und Forschungen zur Geschichte Sachsen-Anhalts, 6 (Köln - Weimar - Wien, 20o9), p. 248, Note 29.

91 Laband, "Eine bisher unbekannte Rechtshandschrift", pp. 44-51.

$92 \quad$ Ibid., pp. 50-51. 
the first one, is rubricated in red ink, and the initials are two lines in height. At the top of Article 1, a space is left blank for an initial that was to be eight lines in height.

The first quire of Part Two contains the Weichbild (f. 127-134v) and a digest of the Sachsenspiegel (f. 135-138). The digest spills over to the pages of second quire, which also contains provisions of the Lübeck Law (f. 141) and a note concerning debt, written in another hand (f. 141). These are followed by auctoritates legistice, that is, legal maxims (f. 141v-142) and some official documents from Słupca. Notes dated 1455, 1459, 1466, and 1468 make reference to two mayors of Słupca: Marcin and Andrzej. ${ }^{93}$ After a few pages which were left blank (f. 144-149v), there follows a note about the diversification of the punishment for theft depending on the circumstances of the case. As this overview suggests, the second part of volume functioned over a fairly long period as a repository of texts used for practical purposes. The copying of the Weichbild was completed on the Invocavit Sunday (16 February) of 1368 (f. 134v). Possibly, the fact that both parts of the manuscript were completed at about the same time was not accidental, and as the copying of the Weichbild was finished, the two manuscripts could be bound into one volume. Be that as it may, Part Two remains an autonomous collection of regulations assembled around the slightly trimmed Weichbild (Articles 31, 48, 55, 71, 94, 95, and 98 are left out) and digests of Sachsenspiegel and the Lübeck Law. The level of coherence of the two parts is hard to assess. Checking the cross-references added to some provisions of the Weichbild (Articles 3, 4, 10, 90, 97, 99, and 106) is not of much help, either. They all refer the reader to Book II or Book I (II libro registro), but only in the first three cases does the reference include the number of the relevant article - presumably of the Sachsenspiegel. And out of these, only one link connects provisions that have something in common (the reference from Article 10 of the Weichbild to Article 66 Book I of the German-language Sachsenspiegel in Part One).

\subsection{Mikotaj of Smogorzewo's Ms (1421) in the National Library in Warsaw, BN 126 oo III $^{94}$}

Manuscript BN 1260o III, which used to be part of the Baworowscy Collection (MS 998) and is now held by the National Library (Acc. 9862), was compiled by

93 The catalogue of medieval manuscripts held in the Library of the Russian Academy of Sciences in St Petersburg refers to Słupsk, correct: Słupca (Ludmila I. Kiseleva, Catalogue des manuscrits médiévaux en écriture latine de la Bibliothèque de l'Académie des Sciences de Russie de Saint-Pétersbourg (Paris, 2005), p. 128).

Hereafter referred to as BN 126oo; Oppitz, Deutsche Rechtsbücher, No. 1453. 
Mikołaj of Smogorzewo. Dated 1421, it contains exclusively landmark texts of German law, ${ }^{95}$ which include: 1) digests (regesta) of the Sachsenspiege ${ }^{96}$ and the Lübeck Law (f. 1ra-4rb); 2) the Sachsenspiegel (f. 4rb-56ra); 3) the Lübeck Law (f. 56ra-64ra); 4) the Weichbild (f. 64rb-8grb); and 5) an article from the Chełmno Law (89va) written in smaller script by a later hand. So far, the Weichbild from this manuscript has not been the subject of a critical analysis. The text, which is very neatly written, is laid out in two columns. The incipits, two lines in height, are preceded by rubrics in red ink. An assortment of legal acts concerned exclusively with municipal law - all written in the same hand (apart from an entry on the last page) - indicates that the manuscript was to function in legal practice in the urban context.

\subsection{Częstochowa ms (1423) in the Archives of the Pauline Fathers in Częstochowa, AJG II-3 ${ }^{97}$}

The Częstochowa MS was given a brief description by Bolesław Ulanowski in the second volume of the Archives of the Law Commission. ${ }^{98}$ Ulanowski dated it to 1423 , in accordance with the date entered in the manuscript itself (f. 107). However, the realization that the quires are not assembled in the correct order led to disagreements over the proper description of the contents of the manuscript. Ulanowski argued that the quires were bound in the wrong order, a mistake that resulted in the separation of two major texts. A landmark source of Magdeburg Law was affected by the division (Ulanowski did not identify it; f. ${ }^{12-36}$ and 139-149), as was the treatise Summa Henrici (f. $37-50$ and 108-138). However, for Oppitz, the binding error resulted in the splitting of the Sachsenspiegel by a fragment of the Summa Henrici (the misplaced f. ${ }^{108-138}$ should have occupied an earlier slot in the codex). In his opinion, the text of the Magdeburg Law on f. 138-145 is in fact the second half of the Sachsenspiegel, cut off from its other half on f. 70-107. He also identified the long text on f. $12 \mathrm{v}-36 \mathrm{v}$ as the Magdeburg Weichbild. As a result, in his catalogue

95 In descriptions of this manuscript, the list and sequence of legal acts that make up its contents are either incomplete or flawed. See Oppitz, Deutsche Rechtsbücher, No. 1453; Ebel and Schelling, Das lateinische lübische Recht, pp. 101-102; and Kaliszuk and Szyller, Inwentarz rękopisów, p. 192.

96 The catalogues name this this body of text Weichbild, yet in fact it is the Sachsenspiegel which begins with the phrase Deus iudex iustus. It is followed by the Lübeck Law.

97 Hereafter referred to as AJG; Oppitz, Deutsche Rechtsbücher, No. 351.

98 Bolesław Ulanowski, "Opisy rękopisów” [Descriptions of Manuscripts], ed. Stanisław Kutrzeba, in: Archiwum komisji prawniczej, 2 (Kraków, 1921), pp. XVII-XVIII. The author of the description published in Archiwum Komisji Prawniczej is named incorrectly in Oppitz's Deutsche Rechtsbücher, No. 351, p. 441. Cf. also Rymaszewski, Eacińskie teksty Landrechtu Zwierciadta Saskiego w Polsce. Versio, Table 6, Item 17. 
the Częstochowa Ms is said to contain two texts of the Weichbild and one text of the Sachsenspiegel.

After taking a careful look at the manuscript itself, I have come to the conclusion that while Ulanowski's account of the consequences of the binding error is essentially correct, his description could do with some extra details. Let me present what - in my opinion - is a definitive list of contents of the Częstochowa Ms. It contains: 1) The Statutes of Kazimierz the Great (f. 1-12v); 2) a digest of the Sachsenspiegel (f. 12v-14); 3) the Sachsenspiegel (versio Vratislaviensis), which begins with the phrase Deus iudex iustus ${ }^{99}$ (f. 12v-36v, f. 139-145); 4) Summa Henrici (f. 108-138, f. 37-50v); 5) the Latin Weichbild (f. 53v-70); 6) a digest of the Sachsenspiegel (f. 70-72); 7) the Latin Sachsenspiegel Landrecht (versio Sandomiriensis), which begins with the phrase Duos gladios (f. 72-107); and 8 ) users' notes (f. 149v). The manuscript thus contains two different Latin translations of the Sachsenspiegel and not, as Oppitz's catalogue would have it, two texts of the Weichbild. All the texts are written in one hand; the script is fairly neat; and the initials are outlined in red ink.

The contents of the Częstochowa MS offer no clear clues about its intended functioning. Although the key texts of the Saxon-Magdeburg Law are given prominence, the manuscript also contains some miscellaneous texts. While the inclusion of Summa Henrici does not sway it in any particular direction, its date of composition (1423) may explain why Polish land law is represented in this collection solely by the Statutes of Kazimierz the Great. At that time, the Statutes of Cracow and Warta were still in the making (1421-1423). ${ }^{100}$ Nonetheless, we are not left completely in the dark about the manuscript's use. A handful of notes on the last leaf points to the municipal court at Sieradz and the High Court of German Law at Kalisz (f. 149v). This is a clear hint that the

99 See Rymaszewski, Łacińskie teksty Landrechtu Zwierciadta Saskiego w Polsce. Versio, p. 21.

100 See Wacław Uruszczak's studies into the dating of the Statutes of Warta and Cracow: "Z badań nad Statutem Warckim z 1423 roku" [Studies of the Statutes of Warta], in: Parlamentaryzm i prawodawstwo przez wieki [Parliamentarism and Legislation over the Centuries], eds. Jerzy Malec and Wacław Uruszczak (Kraków, 1999), pp. 135-147; Wacław Uruszczak, "Nowelizacja Statutów Kazimierza Wielkiego w statucie warckim z 1423 roku. Z badań nad ustawodawstwem w dawnej Polsce" [Amendment of the Statutes of Kazimierz the Great in the Statute of Warta of 1423: Studies in Polish Legislation until the Late 18th Century], in: Studia z Dziejów Państwa i Prawa Polskiego [Studies in the History of Polish State and Law], 9/1, eds. Jacek S. Matuszewski and Wojciech Witkowski (Lublin - Łódź, 2006), pp. 93-108; Wacław Uruszczak, "Rękopisy Statutu krakowskowarckiego z 1421/1423" [Manuscripts of the Statutes of Cracow and Warta, 1421/1423], in: Nil nisi veritas. Ksiega dedykowana Profesorowi Jackowi Matuszewskiemu [Nil nisi veritas: A Festschrift in Honour of Professor Jacek Matuszewski], eds. Marcin Głuszak and Dorota Wiśniewska-Jóźwiak (Łódź, 2016), pp. 99-114. 
manuscript, regardless of the circumstances of its creation, eventually found its way into the hands of legal practitioners administering municipal law. Thus far, there has been no detailed study of the Weichbild in the Częstochowa Ms. ${ }^{101}$

\section{5}

\section{MS Lat. Q II 157 (1427) in the National Library of Russia in St Petersburg ${ }^{102}$}

MS Lat. Q II 157 has survived the ravages of history. According to the provisions of the Treaty of Riga, signed in 1922, it should have been returned to Poland, ${ }^{103}$ but in fact, it never left St Petersburg (Leningrad). In Poland, after the war, it was assumed that it had been handed over, but then destroyed in the Warsaw Rising in $1944 .{ }^{104}$ It resurfaced in 1996 in connection with the publication of Alexandr Rogachevski's monograph The Sword of Roland. Rogachevski also made reference to the manuscript, long thought lost, in another article. ${ }^{105}$

The manuscript deserves an extended description if only because it is a composite made up of three distinctly different parts, written in three hands. The first part consists of four quires, and the next part consists of six. Part I contains a Latin Weichbild (contrary to earlier descriptions, it is neither the

101 For more references, see my articles mentioned in the footnotes to this study.

102 Hereafter referred to as MS Q II 157 (1) and (2).

103 The presence of the manuscript in St Petersburg was confirmed in the 19th century catalogues of Beda Dudík ("Historische Forschungen in der keiserlichen öffentlichen Bibliothek zu St. Petersburg", Sitzungsberichte der kaiserlichen Akademie der Wissenschaften, philosophisch-historische Classe 95/1 (1879, published 188o), p. 362, No.114) and Alfred Blumenstock ("Wiadomość o rękopisach prawno-historycznych Biblioteki Cesarskiej w Petersburgu. Sprawozdanie z poszukiwań” [Latest Information about Legal History Manuscripts in St Petersburg Imperial Library], in: Archiwum Komisji Historycznej. Collectanea ex Archivo Collegii Historici, 6 (Kraków, 1891), pp. 437-438, No. 339).

104 Oppitz, Deutsche Rechtsbücher, No. 1471; Ebel and Schelling, Das lateinische lübische Recht, pp. 102-103.

105 Alexander Rogatchevski, Mech Rolanda: pravovye vzgliady nemetskikh gorozhan XIIIXVII vv. [The Sword of Roland] (St. Petersburg, 1996), pp. 46, 136-137 and 154; Alexander Rogatchevski, "Das Magdeburger Recht auf dem heutigen Territorium Rußlands. Forschungsstand und Forschungsperspektiven", in: Rechts- und Sprachtransfer in Mittelund Ostmitteleuropa. Sachsenspiegel und Magdeburger Recht. Internationale und interdisziplinäre Konferenz in Leipzig vom 31. Oktober bis 2. November 2003, eds. Ernst Eichler and Heiner Lück, (Ivs Saxonico-Maidebvrgense in Oriente) 1 (Berlin, 2008), p. 249, Note 31. Cf. also Oppitz, Ergänzungen, p. 542. See also: Kaliszuk, Codices deperditi, 1, p. 192; Olga Bleskina, Katalog sobraniâ latinskih rukopisej: pravo, filosofiâ, nauka, literatura i iskusstvo / Catalogus codicum manuscriptorum latinorum, qui in Bibliotheca Publica Petropolitana asservantur: jurisprudentia, philosophia, scientia, monumenta litterarum (Sankt-Petersburg, 2011), No. 73, pp. 47-48. 
Weichbild vulgate ${ }^{106}$ nor the German version known as Konrad of Opole's compilation), the Latin Sachsenspiegel (versio Vratislaviensis), and Halle's Legal Instruction for Środa Ślaska (Hallische Rechtsmitteilung für Neumarkt) (f. 1-53v). This is followed by a homily written by the second hand (f. $54 \mathrm{r}-55 \mathrm{r}$ ). The second part, written in the third hand, begins with a new quire. It consists of the Latin Sachsenspiegel (versio Vratislaviensis) and a Latin Weichbild (f. 56r-123v). The text of each of the two Weichbilds represents the versio Sandomiriensis, but they are not identical.

If the reasons for combining two sets of texts of the Saxon-Magdeburg Law are not clear, it is certain that each one had had its own history. The first one, as shown by the inclusion of Halle's Legal Instruction for Środa Ślaska and the replacement of 'burgers of Magdeburg' by 'burghers of Novum Forum [i.e. Neumarkt/Środa Śląska] or of Magdeburg', ${ }^{107}$ had been used in a town founded under a local variant of the Magdeburg Law called in Latin ius Novi Fori or ius Sredense. One consequence of having a compound of two sets of texts like MS Q II 157 (1) and (2) is that only the second (the later) of the two Weichbilds can be used for reliable dating. ${ }^{108}$ The writing in both sets is somewhat careless; decorated initials appear only in Part I (as far as f. 43r), and elsewhere, the spaces provided for such decorations remain blank. There can be little doubt that both parts of this compound manuscript were created for practical purposes.

\subsection{Kielce Ms (1429) in the Library of the Diocesan Seminary in Kielce, RK $45 / 28^{109}$}

Manuscript RK $45 / 28$, held in the collections of the Diocesan Seminary Library in Kielce, is a combination of liturgical and legal texts. Its contents are listed in an inventory published by Jerzy Wolny. ${ }^{110}$ A set of texts of Saxon-Magdeburg Law (f. 95-140v) was compiled by Piotr pauperus, parish priest (rector) of

106 More on the vulgate in: Ebel and Schelling, Das lateinische lübische Recht, pp. 102-103, and Oppitz, Ergänzungen, p. 542. Rymaszewski goes so far as to claim that the text of the first Weichbild in this manuscript is a German version of Konrad of Opole's compilation (Eacińskie teksty Landrechtu Zwierciadta Saskiego w Polsce. Versio, Table 6, Item 13).

107 Cf. Appendix 2, No. 201.

108 Anno Domini millesimo quadringentesimo vicesimo septimo die Sabbathi proxima ante Letare.

109 Hereafter referred to as Ms Kiel.; cf. also Andrzej Kwaśniewski, "Księgozbiory prywatne zachowane w Bibliotece Kapituły Kieleckiej (XV-XVIII w.)”, [Private Collections Held in the Chapter Library in Kielce (15th-18th Century)], Biuletyn Biblioteki Jagiellońskiej 62 (2012), 69 .

110 Wolny, Inventaire des manuscrits, p. 74. This manuscript is also mentioned by Anna Łosowska in her Kolekcja liber legum $i$ jej miejsce $w$ kulturze umystowej 
Potok. According to the explicit, he completed the writing of the Weichbild on 4 August 1429. In addition to the Saxon-Magdeburg Law, the manuscript contains a legal manual entitled Processus iudiciariis and a short legal disquisition. The Processus is written in a hand very similar to that of parish priest Piotr. As the liturgical and the legal texts appear on leaves that belong to different quires and the legal set is written in one hand, it can be assumed that they functioned separately before being bound in this codex. The homilies (f. $36-88 \mathrm{v}$ ) are written in what could be the same hand; moreover, the second Piotr's explicit is situated in folio 86va - parish priest Piotr copied some of the non-legal texts of the manuscript, as well. What also links the homilies and the legal text is the form of their decorative initials penned in red ink. The remaining liturgical texts (e.g. fol. 89-94) are written by various hands. The texts of Saxon-Magdeburg Law in this manuscript have not yet been studied. It is a fair guess that MS Kiel. was used by officials looking after the landed property of the Church.

\subsection{Baworowscy Ms (First Half of the 15th Century) in the National Library in Warsaw, BN 12607 III ${ }^{111}$}

This collection of unknown provenance, formerly in the Baworowscy Collection (No. 1014) and at present held by the National Library in Warsaw (as Acc. 9869), contains a set of legal acts and treatises on urban and canon law, including judgments of the of the High Court of German Law in Cracow (for a description of this bilingual manuscript, see the overview of the German-language texts in Section 2.3). So far, no study has been made of the Weichbild in this manuscript.

\subsection{St Florian Ms (1453) in Sankt-Florian Monastery Library in Austria, 551/II ${ }^{112}$}

A description of the St Florian MS was published by Bolesław Ulanowski. ${ }^{113}$ The Codex used to belong to Tyniec Abbey; in the 19th century, it was sold to the Bishop of Tarnów, Gregor Ziegler. He donated it to the Augustinian Abbey at Sankt-Florian in Austria, from which it took its name. ${ }^{114}$ According to Ulanowski, the St Florian MS, written by two scribes, one of whom copied just the beginning of the Statutes of Kazimierz the Great, consists of two parts.

\footnotetext{
późnośredniowiecznego Przemyśla [The Liber legum MS and Its Place in the Intellectual Culture of Late-Medieval Przemyśl] (Warszawa - Przemyśl) 2007, p. 205.

111 Hereafter referred to as MS BN 12607; cf. also Oppitz, Deutsche Rechtsbücher, No. 1454.

112 Hereafter referred to as ms Flor.; cf. also Oppitz, Deutsche Rechtsbücher, No. 1367.

113 Ulanowski, "Opisy rękopisów", pp. XIX-XXI; and Albin Czerny, Die Handschriften der Stiftsbibliothek St. Florian (Linz, 1871), pp. 187-188.

114 Ulanowski, “Opisy rękopisów”, p. XIX.
} 
Part I, made up of 40 leaves, consists of: (1) the Statutes of Kazimierz the Great, and (2) the Statute of Warta. Part II contains the key texts of the Magedburg Law: (3) the Magdeburg Weichbild (f. 41-58), (6) the Sachsenspiegel (f. 59v$96 \mathrm{v}),(7)$ a digest of the Weichbild (f. $96 \mathrm{v}-98),(8)$ a digest of the Sachsenspiegel preceded by Explicit prologus, incipit ius provinciale (f. 98-102); and the following supplements: (4) De numero ponderum et mensuarum ac diversorum (f. 58-59), (5) two articles from the Statutes of Kazimierz the Great (f. 59), and (9) vocabula libri municipalis (f. 102-102v), that is, a lexicon of the Magdeburg Law. ${ }^{115}$ In his commentaries, Ulanowski places significant stock on the similarities between the texts of Magdeburg Law in the Flor. Ms and the Gn. Ms, shown in particular by the presence in both of the fragment Explicit prologus. He notes also a number of formal differences, such as the removal of identical rubrics from the main text to the digests (regesta). This composite codex brings together two key texts of Polish land law and a set of 'urban' regulations. Its provenance and function are obscure. It was probably not intended for use by a municipal court. The small octavo format, ${ }^{116}$ careless handwriting, and blank spaces left for incipits set it apart from 'quality' manuscripts that are known to have functioned in medieval communes. Stanisław Kutrzeba, who edited Ulanowski's description of the Flor. Ms, picked out the date 1453 inscribed next to the text of the Statutes of Kazimierz the Great and decided that it marked the completion of the entire manuscript. ${ }^{117}$

\subsection{Ms Dziat. 8or (Dziatyńscy Codex I, 1455) in the Kórnik Library of the Polish Academy of Sciences ${ }^{118}$}

The polymorphic Działyńscy Codex I held at the Kórnik Library contains an assortment of historiographical ${ }^{119}$ and legal texts. In his description, Antoni Zygmunt Helcel distinguishes six parts of the codex. Part I contains miscellaneous materials of various provenance; Part II contains a prose narrative of the Trojan War by Guido delle Colonne; Parts III and IV are comprised for the most part text of German law; Part v contains collections of land and feudal law (including the Lehnrecht from the Sachsenspiegel); and Part VI contains a

\footnotetext{
115 The lexicon was published by Ulanowski (ibid., pp. Xx-XXI).

116 The leaves in this manuscript: width $15.2 \mathrm{~cm}$, height $21 \mathrm{~cm}$.

117 Stanisław Kutrzeba, "Opisy rękopisów”, in: Archiwum komisji prawniczej, 2 (Kraków, 1921), p. XXI.

118 Hereafter referred to as Ms Dział. I; cf. also Oppitz, Deutsche Rechtsbücher, No. 837.

119 Jacek Wesołowski, Kolekcje historyczne w Polsce średniowiecznej XIV-XV wieku [Historical Collections in Medieval Poland (14th-15th Century)] (Wrocław - Warszawa - Kraków, 1987), pp. 136-138.
} 
handful of narrative works and a collection of the Magdeburg ortyle (f. 331343) published in the form of a homographic reprint by Michał Bobrzyński. ${ }^{120}$

There is no point in presenting the whole codex here, as its many constituent elements represent different classes of texts, practically independent of one another, that belong to different socio-cultural contexts. It is written in many different hands using various kinds of writing materials. ${ }^{121}$ Stanisław Budka's analysis shows that the writing in quires $13^{-22}$ (f. 141-235) predates $1455{ }^{122}$ whereas quires 12 (f. 129-140) and 21 (f. 236-247) were assembled in 1466. On the basis of Jerzy Zathey's excellent extended description of MS Dział. I and the critical observations of Bolesław Ulanowski, I have compiled a detailed survey of the contents of the fourth part of this multiple-text manuscript (see Table 7).

It is worth noting that the Weichbild is written in two hands. The change from one to the other coincides with the opening of another quire. Another aspect of this shift was brought to light by Stanisław Budka. His research shows that the first three leaves of the Weichbild are 11 years older than the other leaves. However, I am convinced that the red rubrics in both parts of the Weichbild are in the same hand. That would indicate that the creation of the Działyńscy Codex I proceeded gradually and that the copyists at work on the texts of the Saxon-Magdeburg Law were simultaneously copying texts of Polish land law and miscellaneous narratives. Zathey links this codex with the university community and the Benedictine Abbey at Łysa Góra, but also notes some of its characteristics that would suggest a rather different provenance. ${ }^{123}$ Unfortunately, there is not a shred of evidence that could offer a clue as why S [tanisław] of Opatów decided to make a copy of the Weichbild at that very time (1455) and in the village of Solec, of all places.

120 Michał Bobrzyński, ed., Ortyle magdeburskie. Przedruk homograficzny z kodeksu Biblioteki Kórnickiej [The Magdeburg Ortyle: A Homographic Reprint of the Kórnik Library Codex] (Poznań, 1876).

121 Antoni Z. Helcel, Starodawne prawa polskiego pomniki poprzedzone wywodem historyczno krytycznym tak zwanego Prawodawstwa Wiślickiego Kaziémirza Wielkiego w texcie ze starych rękopism krytycznie dobranym [Ancient Monuments of Polish Law with a Critical-Historical Introduction to the Legislation Known as Kazimerz the Great's Statute of Wiślica: A Critical Edition of Its Text Collected from Old Manuscripts] (Warszawa, 1856), p. XXVIII. Helcel's description of this manuscript is far more comprehensive than that of Jan W. Bandtkie in his Jus Polonicum, codicibus veteribus manuscriptis et editionibus quibusque collatis (Varsaviae, 1831, p. Xv). Both have been superseded by the detailed analyses of Jerzy Zathey (Katalog rękopisów średniowiecznych Biblioteki Kórnickiej [A Catalogue of Medieval Manuscripts in Kórnik Library] (Wrocław, 1963), p. 449).

122 Zathey, Katalog, pp. 449-45o.

123 Ibid., p. 453. 
TABLE 7 Contents of Part IV of Działyńscy Codex I

\begin{tabular}{|c|c|c|c|}
\hline $\begin{array}{l}\text { Folium } \\
\text { number }\end{array}$ & Contents & Hand $^{\mathrm{a}}$ & Notes \\
\hline 129 & $\begin{array}{l}\text { rules concerning the } \\
\text { size of the Frankish } \\
\tan (H u f e)\end{array}$ & A & - \\
\hline 129 & $\begin{array}{l}\text { excerpt from a Latin- } \\
\text { Polish lexicon of legal } \\
\text { terms of German law }\end{array}$ & A & - \\
\hline $129 \mathrm{~V}$ & $\begin{array}{l}\text { oath formulas } \\
\text { according to German } \\
\text { law }\end{array}$ & A & - \\
\hline $129 \mathrm{~V}$ & sample legal formulae & A & - \\
\hline $130-132$ & $\begin{array}{l}\text { a brief digest of the } \\
\text { Weichbild }\end{array}$ & A & - \\
\hline $132 \mathrm{~V}-137$ & $\begin{array}{l}\text { a brief digest of the } \\
\text { Sachsenspiegel }\end{array}$ & A & 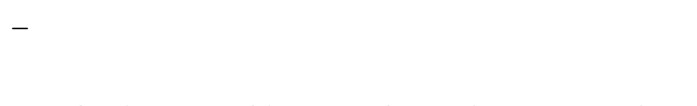 \\
\hline $137 \mathrm{~V}-17 \mathrm{OV}$ & $\begin{array}{l}\text { The Magdeburg } \\
\text { Weichbild }\end{array}$ & $\begin{array}{l}\mathrm{B}^{\mathrm{b}} \text { and } \mathrm{C} \\
\text { from } 141 \\
\text { onwards }\end{array}$ & $\begin{array}{l}\text { Hand C (autograph): S[tanisław] of z Opatów, }{ }^{\mathrm{c}} \text { f. } \\
170 \mathrm{o} \text {, job completed } 22 \text { November } 1455 \text {, Solec; in } \\
\text { the same hand - the text of the Polish translation } \\
\text { of the Statutes of Kazimierz the Great (f. } 265^{-298} \text {, } \\
\text { except } 296-298)^{\mathrm{d}}\end{array}$ \\
\hline $171-174 \mathrm{~V}$ & varia & $\mathrm{D}$ and $\mathrm{E}$ & - \\
\hline $175^{-238}$ & The Sachsenspiegel & $\begin{array}{l}\text { F; } \\
\text { G from } \\
227 \mathrm{~V} \\
\text { onwards; } \\
\text { and } \\
\mathrm{H} 236\end{array}$ & $\begin{array}{l}\text { Hand H f. } 238 \text { (autograph): 1466; (inscribed by } \\
\text { H) summa of the Statutes of Kazimierz the Great } \\
\text { and the Statute of Warta, }{ }^{\text {e }} \text { and (f. } 296-298 \text { ) the } \\
\text { translation of the Statutes of Kazimierz the Great, } \\
\text { Lehnrecht from the Sachsenspiegel (1469), the Story } \\
\text { of Apollonius King of Tyre and the final part of the } \\
\text { collection of Magdeburg ortyle }\end{array}$ \\
\hline $239 v-246$ & $\begin{array}{l}\text { A compendium } \\
\text { of German law in } \\
\text { essential rules }\end{array}$ & I & - \\
\hline
\end{tabular}

a The hands in Part IV are labelled A - I.

b Helcel's reference to a change of hand on f. 133v. must be a printer's error. The change occurs on f. 132v.

c Jerzy Zathey does not rule out that this entry may refer to Stanislaus Martini Institoris de Opathow, enrolled at the University of Cracow in 1424 (Zathey, Katalog, p. 451).

d Helcel, Starodawne prawa polskiego pomniki, p. XxxıII.

e Ibidem, p. XxxiII. 
Zygmunt Rymaszewski used the texts of the Działyńscy Codex I and the Gniezno Ms in his analysis of the Sandomierz version of the first redaction of the Latin Sachsenspiegel. Interestingly, the Weichbild in Ms Dział. I is closest to the text in the oldest surviving manuscript MS Gn., and its importance as source is greatly enhanced by its gloss, evidently written by a user (see Chapter 4.2 of this study).

\subsection{Ms Dziat. 8oo (Dziatyńscy Codex IV, after 1472) in the Kórnik Library of the Polish Academy of Sciences ${ }^{124}$}

The first extended description of the Działyńscy Codex IV from the Kórnik Library was published by Antoni Z. Helcel in Volume I of his Ancient Monuments of Polish Law; a precise analysis of the manuscript was recently written by Jerzy Zathey. ${ }^{125}$ MS Dzial. IV contains a sizable collection of acts of Polish law, the Weichbild (f. 102-145), and the Sachsenspiegel Landrecht (f. 146-240) - all of which are in one hand. Helcel claims that the provenance of the Działyńscy Codex IV must be Mazovia, because the Magdeburg Weichbild in this manuscript contains a few quotations from the Chełmno Law (Der Alte Kulm). ${ }^{126}$ However, this argument fails to persuade. Moreover, none of the key texts of Polish law, a significant number of which have survived, ever mentions the statutes or customs of Mazovia. In effect, the provenance of this text needs to be re-examined (see Chapter 2.6 and 4.2.5 of this study). Zygfryd Rymaszewski observes that the Weichbild and the Sachsenspiegel in the Działyńscy Codex IV are in a way distinct, but he stops short of postulating the presence of another Latin translation to account for the difference. His solution is to classify the Weichbild of Ms Dział. IV as the second redaction of the versio Sandomiriensis. ${ }^{127}$ He argues that the author of the Działyńscy Codex IV stripped the Weichbild of provisions that can be found in the Sachsenspiegel for reasons of economy (however, this is stated explicitly in the text). ${ }^{128}$ Although, as this discussion demonstrates, the Weichbild of the Działyńscy Codex IV has attracted some scholarly attention, so far it has not been the object of systematic, in-depth analysis. Finally, allow me to correct an incorrect piece of information in the Catalogue of Medieval Manuscripts in the Kórnik Library. The Weichbild from

\footnotetext{
124 Hereafter referred to as ms Dział. IV. Cf. also Oppitz, Deutsche Rechtsbücher, No. 836 .

125 Helcel, Starodawne prawa polskiego pomniki, pp. XLII-XLV; and Zathey, Katalog, pp. 445449. Cf. also Bandtkie's introductory note to Jus Polonicum (p. XVI).

126 Helcel, Starodawne prawa polskiego pomniki, pp. XLII-XLIII; Rymaszewski, Łacińskie teksty Landrechtu Zwierciadta Saskiego w Polsce. Versio, pp. 73, 76; and Zathey, Katalog, p. 448.

127 Rymaszewski, Łacińskie teksty Landrechtu Zwierciadła Saskiego w Polsce. Versio, pp. 73 and 76 .

128 Ibid., p. 71.
} 
the Działyńscy Codex IV did not go to print in Jan Łaski's Statutes; he used a different text. ${ }^{129}$

\subsection{Liber legum of Przemyśl (1473-1474) in the State Archive in Przemyśl, AMPrzem. $428^{130}$}

The Liber legum (Law Book) of Przemyśl, held in the Przemyśl State Archive (Acts of the Town Przemyśl, Shelfmark 428), is the subject of a monograph by Anna Łosowska. ${ }^{131}$ She divides the texts of that codex into three groups: the Saxon-Magdeburg Law collection, texts of Roman and canon law, and historiographical works. The catalogue of documents in the category of German law is exceedingly long. The codex opens with the Magdeburg Weichbild, preceded by an index of rubrics and followed by a note marking the completion of this copying job on 5 March 1473 (f. 13r-27r). It also contains the Sandomierz version of the Sachsenspiegel, followed by a note marking the completion of this copying job in 1474 (f. 27v-61r). Both texts are written in one hand (we are told that the scribe's name is Stanisław). ${ }^{132}$ The Law Book of Przemyśl also contains the Wrocław version of the Sachsenspiegel (the Landrecht with the Lübeck Law and the Lehnrecht, f. 118r-149r and f. 168r-19or, respectively); a collection of the Magdeburg ortyle, including some translated in Przemyśl (f. 63r-68r, 70r-74v);133 the Law Book of Środa Ślaska (Das Rechtsbuch der Stadt Neumarkt in Schlesien) (f. 102r-103v); ;34 a manual of canon and Roman, law Summa legum levis, brevis et utilis, by Master Raymundus (Parthenopaeus), used as an auxiliary law book in urban courts (f. 312-388); a digest of the Sachsenspiegel with supplementary material from Roman law (f. 68r-69v and 76r-102r); a lexicon of legal terms of Magdeburg Law (f. 162-163); and Gregory XI's and Urban VI's bulls condemning certain provisions of the Sachsenspiegel. ${ }^{135}$ Łosowska notes

129 Zathey, Katalog, p. 448.

130 Hereafter referred to as Ms Przem. Cf. also Oppitz, Deutsche Rechtsbücher, No. 1296; Ebel and Schelling, Das lateinische lübische Recht, pp. 99-100.

131 Łosowska, Przemyska Liber legum. For earlier studies, see the bibliography in Łosowska's monograph. The first extended description of this manuscript was written by Kałużniacki, "Die polnische Recension", pp. 220-226.

132 Łosowska ventures the conjecture that the copyist of the Weichbild and the Sachsenspiegel in the Przemyśl Liber legum and the scribe of Ms Dział. are one and the same person, Stanisław of Opatów. Cf. Łosowska, Liber legum, pp. 186-187.

133 Ibid., p. 225.

134 Iura que dicuntur Withbilde (ibidem, pp. 210 and 228-230). Law Book of Środa Ślaska is dated to c.1335/1337; at its core is Halle's Legal Instruction for Środa Ślaska (Hallische Rechtsmitteilung für Neumarkt) of 1235. Cf. also Oppitz, Deutsche Rechtsbücher, 1, p. 6 o.

135 Łosowska, Liber legum, p. 173. 
that the codex is an agglomeration of elements that at least partially functioned as separate manuscripts:

Some quires have their own numbering scheme which additionally sets off the texts thus marked from the rest of the codex. This is another piece of evidence to support the argument that the individual texts used to function separately. Those texts are Speculum Saxonum, ${ }^{136}$ Ius feodale, ${ }^{137}$ the Przemyśl redaction of the Magdeburg ortyle, a treatise on canon law [Defesorium iuris] by Gerardus Monachus, Summa legum by Raymundus Parthenopaeus and the Decretalia. ${ }^{138}$

The orderly arrangement of quires, she insists, should be treated as proof that the composition of codex was well planned by its author, Szymon of Jaworów. 139

An important implication of this discussion is that the copyist of the Latin Weichbild and Sachsenspiegel (representing the versio Sandomiriensis) must not be identified with the author of the codex or any of its various parts. While Feliks Kiryk links the creation of the Liber legum with the growth and rising status of Przemyśl's urban community, ${ }^{140}$ Łosowska is convinced that "the origin, or at least the use, of the Przemyśl collection [was connected] with the local ecclesiastical elite". ${ }^{141}$ Yet she does not rule out that the former owners of some books in the codex were members of the urban elite, connected with the town chancery. As the municipal records have not survived, the claim that the judgments of the High Court of German Law in Cracow were translated into Latin by a local man, "former town clerk of Przemyśl" (per quendam notarium

\footnotetext{
136 I.e. versio Vratislaviensis.

137 The Sachsenpiegel-Lehnrecht.

138 Łosowska, Liber legum, pp. 170-171

139 Ibid., pp. 168-170, 175, 177, 184, and 337.

140 Feliks Kiryk, "Przyczynki do dziejów szkolnictwa i stosunków kulturalnych późnośredniowiecznego Przemyśla” [Some Highlights of the History of Education and Cultural Relations in Late-Medieval Przemyśl], in: Cracovia, Polonia, Europa: studia z dziejów średniowiecza ofiarowane Jerzemu Wyrozumskiemu w sześćdziesiąta piąta rocznicę urodzin i czterdziestolecie pracy naukowej [Cracovia, Polonia, Europa: A Festschrift Dedicated to Professor Jan Szymczak on His 65th Birthday Anniversary and 40 Years of Academic Work], eds. Krzysztof Baczkowski, Waldemar Bukowski, Mariusz Markiewicz, Krzysztof Ożóg, Maciej Salamon, Franciszek. Sikora, and Stanisław Szczur (Kraków, 1995), pp. 361-371; Feliks Kiryk, "Ze stosunków ustrojowych w późnośredniowiecznym Przemyślu", in: Parlamentaryzm i prawodawstwo przez wieki, eds. Jerzy Malec, Wacław Uruszczak (Kraków, 1999), pp. 271-282.

141 Łosowska, Liber legum, p. 188.
} 
civitatis Przemisliensis), cannot be dismissed out of hand. ${ }^{142}$ Nor can we simply reject the old story which credits Szymon of Jaworów with collecting all the books of urban law he could find, and no doubt a place where they could be found was the town chancery. In this study, at least one part of the story is confirmed, namely, the Weichbild of the Przemyśl Liber legum does come from a chancery background.

Łosowska also compared the Weichbild of the Przemyśl Liber legum with that of the Działyńscy Codex IV. ${ }^{143}$ Her conclusion is that both texts were written in the 15th century by anonymous authors and that in both collections, the Weichbild is followed by the Sachsenspiegel. Although this sequence is peculiar to these two manuscripts, she does not believe they have a common ancestor (and neither do I). ${ }^{144}$ Her analysis focuses on the differences between the two texts, such as the divergences in the wording and the arrangement of some articles from the beginning of the Weichbild, in Article 43, the formula of the Jewish oath, and the phrasing of the rubrics. ${ }^{145}$ The asymmetry between the two texts is visibly heightened by errors in article numbers, the adoption of lumps of the Chełmno Law (MS Dział. IV), and the insertion of 14 articles without numbers after the Jewish oath (MS Dział. IV). ${ }^{146}$ Łosowska also compared the Weichbild of the Przemyśl Liber legum with Łaski's Statutes. In this case, her conclusion is that the two texts do not share a common base and that Łaski's Weichbild begins with a long introduction which is missing in Przemyśl Ms. ${ }^{147}$

There is little to disagree with in terms of her findings. After all, each of the three texts belongs to a different branch of the Weichbild filiation tree: Przemyśl ms; the Działyńscy Codex IV; and the Statutes.

\subsection{Pleszew MS in the Acts of the Town of Pleszew I/2 (until 1498) in the State Archives in Poznañ 148}

The Book of Pleszew Town Council opens with the first 54 articles of the Weichbild. Their sequence corresponds with that of the Gniezno Ms (f. 51-55). To this batch, two more articles are added of unidentified provenance, each in a different hand. The Weichbild text from the Pleszew ms was published

\footnotetext{
142 Ibid., p. 185.

143 Ibid., pp. $205^{-206 .}$

144 Ibid., p. 206.

145 Ibid., pp. 207-209.

146 Ibid., p. 209. Actually, the 14 articles are a supplement to the Weichbild known as the Constitution of Courts.

147 Ibid., p. 209.

148 Hereafter referred to as ms Plesz. Cf. also Oppitz, Deutsche Rechtsbücher, No. 1219.
} 
by Witold Maisel; ${ }^{149}$ the Book of Pleszew Town Council was published in two instalments, with Part I edited by Tomasz Jurek, and Part II edited by Adam Kozak. ${ }^{150}$ Maisel's description embraces all the characteristic features of the Pleszew Weichbild extract (hand, ductus, initials, rubrics). On the subject of filiation, he merely notes that the Pleszew text shows some similarities with one of the texts in taski's Statutes, ${ }^{151}$ and in a footnote, he refers the reader to Mikołaj Jaskier's Iuris Municipalis. While Maisel dates the writing of the Pleszew Weichbild to 1519/1520, Adam Kozak makes a strong case for dating it back to the 15th century, before $1483 .{ }^{152}$ The reasons why only the first part of the Weichbild was copied are not clear. Agnieszka Bartoszewicz notes that the practice of copying legal texts into municipal records was not uncommon and cites the cases of Krzywin and Radziejów, whose town council books contain judgments of the High Court of German Law at Kościan (Kosten) and provisions of the Chełmno Law, respectively. 153

\subsection{Opatów Ms (1488) in the Ossoliński National Institute, Oss. $83^{2} / \mathrm{II}^{154}$}

According to a sketchy description by Wojciech Kętrzyński, the Opatów Ms is a 15th-century paper codex written carelessly in one hand. ${ }^{155}$ Its date of origin, 1488 , is mentioned in a summary in the last part of the manuscript. It proclaims that:

... here end the books of Magdeburg and Saxon Law authorized by Emperor Otto, written and completed by one Mikołaj, cleric of the

\footnotetext{
149 Witold Maisel, "Prawo magdeburskie miasta Pleszewa" [The Magdeburg Lawbook of Pleszew], Studia i Materiaty do Dziejów Wielkopolski i Pomorza 9/1 (1963), 67-82.

15 O Tomasz Jurek, ed., "Najdawniejsze zapiski z księgi miejskiej Pleszewa (1428-1444)” [The Earliest Records in the Book of Pleszew Town Council (1428-1444)], in: Wielkopolska dawniej i dziś. Studia, źródta i materiaty [Wielkopolska in the Past and Today: Studies, Sources and Materials], ed. Andrzej Gulczyński, (Kwartalnik Historii Kultury Materialnej) 6o/3 (2012) (Poznań, 2011) and Adam Kozak, transl. and ed., Najstarsza pleszewska księga radziecka: zapiskiz lat 1485-1519 [The Oldest Volume of the Book of Pleszew Town Council: Records 1485-1519], (Wielkopolska Dawniej i Dziś) 4 (Poznań, 2014).

151 Maisel, "Prawo magdeburskie", pp. 68-69.

$15^{2}$ Adam Kozak, "Introduction", in: Najstarsza pleszewska księga radziecka, p. 8.

153 Agnieszka Bartoszewicz, Piśmienność mieszczańska w późnośredniowiecznej Polsce [Urban Literacy in Late Medieval Poland] (Warszawa, 2012), p. 114.

154 Hereafter referred to as ms Oss.

155 See description of the manuscript: Bischoff, "Beiträge zur Geschichte", pp. 341-345; Wojciech Kętrzyński, ed., Catalogus Codicum Manuscriptum Bibliothecae Ossolinianae Leopoliensis. Katalog rękopisów Biblioteki Zakładu Nar. Im. Ossolińskich, 3 (Lwów, 1898), pp. 276-277; Oppitz, Deutsche Rechtsbücher, nr 281.
} 
Gniezno diocese and court clerk, in A.D. 1488 on the Friday before the carnival, dies Veneris, 15 th February at Opatów.

The codex opens with the Weichbild (f. 1ra-17ra as capitula $5^{1-157), ~ f o l l o w e d ~ b y ~}$ the Sachsenspiegel in versio Sandomiriensis (f. 17ra-57va, capitula 158-439). The pagination is continuous, with the exception of the third text in this set, that is, a Latin translation of the Sachsenspiegel, versio Vratislaviensis, divided into 237 capitula (f. 57va-104va). The codex also comprises the acts of the town of Jihlava (German Igel) in Bohemia ${ }^{156}$ (Iura seu statuta Iclaviae civitatis, f. 105-117r) and two legal collections, Breviloquus liber de iure valde utilis - a Latin translation of Magdeburg judgments (ortyle/Urteile) (f. $117 \mathrm{r}-128 \mathrm{v}$ ); and De propositionibus actoris et responsionibus rei (f. $128 \mathrm{v}-129 \mathrm{v}$ ), addressed to the aldermen of Lwów. These are clearly separated from the texts of Saxon-Magdeburg Law. The last item in this collection is a short treatise, Modus vivendi (f. 129v-132r). The rubrics are outlined in red, at times too sparsely. As a result, some headers run over to the outer margin or the inner margins between two columns of text. Unfortunately, the first five leaves of the manuscript have been damaged. In his description, Ferdinand Bischoff claims that the texts in the Opatów MS are closest to those in Łaski's Statutes. ${ }^{157}$ This claim will be examined in Chapter 2 of this study. Let me add that the various attempts to trace the filiation of Łaski's texts cannot be verified. This is the case with the alleged similarities between the Statutes and the Sanok Ms (see 3.19 below) and the so-called Ms Petersburg III. ${ }^{158}$ The former has been written off as lost, and the latter was destroyed in a blaze.

\subsection{4 Żegota Pauli's Ms (Second Half of the 15th Century) in the Jagiellonian Library, BJ $4405^{159}$}

Stanisław Estreicher wrote a description of the Żegota Pauli's Ms while he was working on his study of the Magedburg ortyle. ${ }^{160}$ There was never any

${ }_{15}$ Incorrectly identified as Illaviae in Kętrzyński's catalogue. The acts are in Latin translation.

157 Cf. Bischoff, "Beiträge zur Geschichte", p. 333.

158 Helcel, Starodawne prawa polskiego pomniki, p. XLV. This manuscript was kept until 1924 in the Imperial Library in St Petersburg Shelfmark Lat. F II 124. Oppitz, Deutsche Rechtsbücher, nr 1466. Description: Helcel, s. XLV-XLVII.

159 Hereafter referred to as BJ 4405. Cf. also Oppitz, Deutsche Rechtsbücher, No. 86o.

16o Estreicher, "Nieznane teksty ortyli", pp. 118-126; Maciej Mikuła, "Weichbild magdeburski w rękopisie Biblioteki Jagiellońskiej nr 4405" [The Magdeburg Weichbild in MS BJ 4405], in: Nil nisi veritas. Księga dedykowana Profesorowi Jackowi Matuszewskiemu [Nil nisi veritas. A Festschrift Dedicated to Professor Jacek Matuszewski], eds. Marcin Głuszak and Dorota Wiśniewska-Jóźwiak (Łódź, 2016), pp. 147-159. 
doubt about the intentions of the author of the Żegota Pauli's mS (BJ 4405). ${ }^{161}$ If it is judged it by its contents, the purpose of creating this collection was unabashedly practical. One part of the manuscript, written in late $15^{\text {th-century }}$ hand, contains: ${ }^{162} 1$ ) a register of 281 ortyle (f. $1-5$ ), Hand A; 2 ) a compendium of German law in the form of key legal rules (the same work can be found in Działyńscy Codex I, f. 239-246) (f. 5 v-9v), Hand B; 3) a digest of the privileges issued by Kazimierz the Great in 1336, 1342, 1358, and 1363, Hand B; 4) Magdeburg ortyle (f. 11-88); 5) a handful of legal maxims and two prescriptions (f. 8gv); and 6) the Weichbild - in the same hand as the ortyle, except the passage de imperio et terra Saxonum, which is written in a different hand (f. 89-107v). A special feature of this codex is the digests of the four royal privileges addressed to Cracow, which are concerned with the competences of the city council; inheritance and family law; criminal law; and other important subjects. The new legislation in the form of royal statutes and confirmations of Cracow's own statutes (by-laws, wilkierze/Willküren) supplemented or amended the Saxon-Magdeburg Law, which remained the mainstay of Cracow's legal order. Additionally, the contents of the second part of Żegota Pauli's Ms bear witness to the codex's practical intent. It includes: a digest of 13 articles of the Chełmno Law (f. $108 \mathrm{r}-108 \mathrm{v}$ ); a digest in Polish of the privileges (including the most recent one from the year 1521, f. 114r-137v); and three normative acts adopted by the Cracow goldsmiths (including the most recent one from the year 1549, f. 140-142). The special connection of MS BJ 4405 with Cracow is all too obvious.

\subsection{Warsaw $\mathrm{ms}$ (Second Half of the 15th Century) in the University of Warsaw Library, Warsz. $5^{163}$}

The Warsaw Ms has survived in incomplete form. The lost leaves at the beginning of the codex contained the first 74 articles of the Magdeburg Weichbild. ${ }^{164}$ The remaining articles, Articles $75^{-110}$, are written on $\mathrm{f}$. 1-7v. The next batch (f. 8-40) contains the second redaction of the Sandomierz version of the Latin Sachsenspiegel. It is followed by the first nine articles of the German-language Sachsenspiegel (versio Vratislaviensis), (f. 41-43), the Jewish oath (f. 79v-8ov), and Book I of Summa legum brevis, levis et utilis by Master Raymundus (f. 46,

\footnotetext{
161 Żegota Pauli was the owner of the Ms in 19th Century.

162 Estreicher, "Nieznane teksty ortyli", pp. 119-121.

163 Hereafter referred to as Ms Warsz. Cf. also Oppitz, Deutsche Rechtsbücher, No. 1481.

164 Helena Kozerska and Wanda Stummer, eds., Katalog rękopisów Biblioteki Uniwersyteckiej $w$ Warszawie [A Catalogue of Manuscripts in the University Library in Warsaw], 1 (Warszawa, 1963), pp. 7-9.
} 
82r-97v). ${ }^{165}$ After a number of articles of the Sachsenspiegel and following the first part of the Summa legum, several leaves have been left blank, probably to be filled in later. However, for an unknown reason, this gap was never resolved, and the leaves remain blank. Whereas the manuscript as a whole is written in a number of hands, the Weichbild and the Latin Sachsenspiegel are the product of just one copyist. His hand is exceptionally neat. The initials, three lines in height, are executed in red; the text in the rubrics is in red ink, too.

\subsection{6 Żagan $\mathrm{Ms}$ (15th Century) in the Wroctaw University Library, II $Q 4^{166}$} The profile of the bilingual Żagan MS retained in the Library of the University of Wrocław is presented in Section 2.3

\subsection{Leipzig Ms (15th/16th Century) in the University Library in Leipzig "Albertina", $951 b^{167}$}

Written in one hand, the Leipzig MS contains the following texts of SaxonMagdeburg Law: ${ }^{168} 1$ ) the Sachsenspiegel-Landrecht (Konrad of Sandomierz's version) (f. 1-78); 2) Capitulum de electione consulum (f. 78v); 3) Konrad of Sandomierz's Magdeburg Weichbild (f. 84-129v, f. 130 blank); 4) a brief digest of the Sachsenspiegel (f. 131); and 5) a brief digest of the Weichbild, which lists two articles that do not appear in the text above (f. 132-134). The catalogue also mention as a separate item a block of 14 non-numbered articles of the Weichbild, which match Articles VI-XIV in Alexander von Daniels and Franz von Gruben's edition of the Weichbild vulgate. ${ }^{169}$ These provisions come from the Constitution of Courts, usually appended to the Weichbild after the Jewish oath. The displacement of Articles 89-93 from their correct slot to a position after Article 56 is due to a binding error. The Leipzig Ms has been dated to the late $15^{\text {th/early }} 16$ th century for no better reason than its affinity to other sources from that period, such as the Marcin Zabowski's Ms (BOz) and Łaski's Statutes (see Chapter 2.2.3). The history of the Leipzig MS is unknown, but some additional notes in the text itself include Polish equivalents of words in the main body (e.g. inducie vulgariter rokiy), ${ }^{170}$ which suggests a strong Polish connection. A note in 19th-century hand pencilled in on the margin says that

\footnotetext{
165 Rymaszewski, Łacińskie teksty Landrechtu Zwierciadta Saskiego w Polsce. Versio, Table 6.

166 Hereafter referred to as MS II Q 4. Cf. also Oppitz, Deutsche Rechtsbücher, No. 268.

${ }_{167}$ Hereafter referred to as MS 95ıb. Cf. also Oppitz, Deutsche Rechtsbücher, No. 89o.

168 Rudolf Helssig, Die lateinischen und deutschen Handschriften der Universitätsbibliothek Leipzig, 3: Die juristischen Handschriften (1926, repr. Wiesbaden, 1996), pp. 88-89; Oppitz, Deutsche Rechtsbücher, p. 632.

169 Helssig, Die lateinischen und deutschen Handschriften, p. 89.

170 Articles 21 and 53.
} 
the manuscript was bought by the University Library in Leipzig for the price of 10 marks. It is just a possibility that the book was brought to Leipzig from the Congress Kingdom of Poland after the defeat of the November Rising $(1830-1831)$.

\subsection{Tomasz of Bydgoszcz's Ms (Early 16 th Century) in the National Library in Warsaw, BN 3068 III $^{171}$}

Manuscript BN 3068, now held in the National Library, was returned to Poland from Leningrad (St Petersburg) after the end of World War I. It had been seized by the Russians with other books from the Załuscy Library in Warsaw after the Third Partition of Poland in 1795 and transferred to the Imperial Public Library in St Petersburg. There, it had the shelfmark Lat. F II 191. Dated to the early 16th century, BN 3068 is a late arrival and may have been completed after the publication of Jan Łaski's Statutes (see Chapter 2.2.3). There is no uncertainty about the scribe, however. His name is Tomasz of Bydgoszcz (f. 227ra). ${ }^{172}$ The volume contains the key texts of the Saxon-Magdeburg Law and a miscellany of excerpts and short notes. The most comprehensive list of its contents can be found in a description by Ebel and Schelling. The following list is based on that record supplemented with information from the National Library inventory of medieval and early 16 th-century manuscripts: 1 ) an astrological treatise (f. $1 \mathrm{r}-1 \mathrm{v}) ; 2$ ) a systematic digest of the Sachsenspiegel, arranged according to subject - the beginning of the text is missing (f. 2ra-19va); 3) the Weichbild, rubricated as Book I (f. 2ora-45vb) plus a series of provisions on f. 42-45 listed in the National Library inventory as an extract from the Weichbild - in fact it is a quasi-separate text called the Constitution of Courts, often appended to the Weichbild after the Jewish oath; 4) the Sachsenspiegel (versio Vratislaviensis), rubricated as Book II, together with the Lübeck Law (f. 45vb-102vb) - note that the sequence Weichbild - Sachsenspiegel - Lübeck Law is identical in Commune incliti; 5) an extract from versio Sandomiriensis of the Sachsenspiegel, mainly provisions concerning family law (f. 103ra-108rb); 6) a compilation of

171 Hereafter referred to as MS BN 3068. Cf. also Oppitz, Deutsche Rechtsbücher, No 1459. In Oppitz's catalogue and Ebel and Schelling's article, the manuscript's shelfmark is cited incorrectly as BN III 3065 .

172 Kaliszuk and Szyller, Inwentarz rękopisów, p. 9o; Dziedzictwo kulturowe po klasztorach skasowanych na ziemiach dawnej Rzeczpospolitej oraz Ślasku w XVIII i XIX w.: losy, znaczenie, inwentaryzacja [The Cultural Heritage of Monasteries Dissolved on the Territory of the Polish-Lithuanian Commonwealth and in Silesia in the 18th and 19th Century: History, Significance, Stock-taking], a data base sponsored by the Ministry of Science and Higher Education in the framework of the National Programme of the Development of the Humanities in 2012-2016, http://pw.kasaty.pl/rekopis/Scroll/4384. html?search=bydgoszcz (Accessed: 18 March 2015). 
materials from the Sachsenspiegel, Roman and canon law - the text is of Polish provenance (f. 108rb-146rb); 7 ) a treatise in 24 books for practitioners of urban law (f. 146va-221vb); 8) extracts from the Weichbild (223vb-224rb); 9) coin conversion tables (f. 224rb-226va); 10) a lexicon of legal terms of Magdeburg Law (f. 224vb-226va); 11) oath formulas (f. 226vb-227va); and 12) a prescription $(228 \mathrm{vb})$. The Weichbild is flanked with numerous glosses and annotations (for a more detailed analysis, see Chapter 4 of this study).

\subsection{Marcin Zabowski's Ms (1513) in the National Library in Warsaw, BOZ $90^{173}$}

This paper manuscript, completed in 1513 by Marcin Zabowski of Lwówek, ${ }^{174}$ used to be held in the collection of the Library of Zamoyski Estate. ${ }^{175}$ It contains the Sachsenspiegel (versio Sandomiriensis) (f. 1ra-45va) and the Weichbild (f. 45va-6gva). The third text, which is introduced in the text by the rubric Incipit De imperio terre Saxonie ius suum ab inicio statutum fuerit et confirmatum, is in fact the Constitution of Courts, often appended to the Weichbild (f. 66vb-6gva). The contents and thematic scope (see Chapter 2.2.3) of the MS воz position it very closely to the earliest extant Latin Weichbild from Gniezno Ms. Among the things they have in common are certain phrases that refer to the Sachsenspiegel and the Weichbild and the special treatment of the provisions of the Constitution of Courts.

\subsection{Sanok ms (Early 16th Century) in the Central National Archives of Ukraine in Lwów (Fonds Sanok 438) - Now Lost ${ }^{176}$}

The Sanok Ms is known exclusively from descriptions, including one by Emil Kałużniacki. ${ }^{177}$ The paper manuscript had been held in the Central Historical Archives of Ukraine in Lviv' until its disappearance, which may have predated 1982, the year when the loss was discovered. ${ }^{178}$ So far, all efforts to explain the circumstances of its disappearance or to ascertain its whereabouts have failed. According to Kałużniacki, the manuscript contained the Magdeburg Weichbild (pp. 3b, 19-44), Konrad of Sandomierz's version of the Sachsenspiegel, a fragment of the Latin translation of the Sachsenspiegel-Lehnrecht, Rechtsbuch nach

\footnotetext{
173 Hereafter referred to as ms Boz. Cf. also Oppitz, Deutsche Rechtsbücher, No. 1457. Oppitz's catalogue mentions only the Sachsenspiegel.

174 See the explicit (f. 69v): Iste liber est finitus per Martinum Zabowskÿ de Lwowek in vigilia Sancte Crucis Anno Domini millesimo quingentesimo tredecimo. Cantor.

175 Kaliszuk and Sławomir Szyller, Inwentarz rękopisów, p. 52.

176 Oppitz, Deutsche Rechtsbücher, No. 929.

177 Kałużniacki, “Die polnische Recension”, pp. 155-159.

178 Oppitz, Deutsche Rechtsbücher, No. 929.
} 
Distinctionen (i.e. the Law Book of Meißen), the Magdeburg ortyle, digests of the Sachsenspiegel-Landrecht, and the Weichbild.179 According to Oppitz's Catalogue, the contents of the Sanok MS were as follows:1) versio Sandomiriensis of the Sachsenspiegel; 2) the Weichbild;3) the Sachsenspiegel-Lehnrecht; 4) versio Vratislaviensis of the Sachsenspiegel; 5) the Law Book of Meißen; and 6) the Magdeburg ortyle. Kałużniacki believes that the Weichbild of the Sanok MS was even closer to Łaski's Statutes than Ms Oss., whose description was provided by Ferdinand Bischoff. ${ }^{180}$ Kałużniacki even goes so far as to claim that in preparing his edition of the Weichbild, Łaski relied heavily on the text of the Sanok Weichbild. Needless to say, none of these claims can be verified.

\subsection{Jan Laski's Statutes (Commune incliti Poloniae Regni privilegium, $1506)^{181}$}

Zygfryd Rymaszewski writes that one of the main objectives of his monograph of the Sachsenspiegel-Landrecht was to examine and profile the text of the Landrecht in Łaski's Commune incliti. His research has established that the Sachsenspiegel in the Statutes is an imaginative compilation of the versio Vratislaviensis and the two redactions of the versio Sandomiriensis. As Łaski's collection of laws enjoyed the status of an official document, the texts that were included in it acquired enormous importance. In his latest study of the Commune incliti, Wacław Uruszczak shows that the official authorization elevated both the rank of the land law (or, more broadly, Polish common law) in the first part of the book, as well sources of the second part. ${ }^{182}$ The latter (Part II) contains:1) an alphabetical index of subjects covered by the provisions

179 In his survey, Rymaszewski does not mention the Lehnrecht and identifies the text of the Sachsenspiegel as Konrad of Opole's version (Rymaszewski, Lacińskie teksty Landrechtu Zwierciadta Saskiego w Polsce. Versio, Table 6. Cf. also Kałużniacki, "Die polnische Recension", pp. 157-159).

180 Kałużniacki, “Die polnische Recension”, p. 157, Note 1.

181 Hereafter referred to as the Statutes. Cf. Karol Estreicher, Bibliografia polska [Polish Bibliography], General Series, 21 (Kraków, 1906), pp. 79-80; Maria Cytowska, Bibliografia druków urzędowych XVI wieku [A Bibliography of Official Documents of the 16th Century] (Wrocław, 1961), No. 1, pp. 53-54; Ebel and Schelling, Das lateinische lübische Recht, pp. 97-98; and Wieland Carls, "Rechtsquellen Sächsisch-magdeburgischen Rechts", in: Inge Bily, Wieland Carls, and Katalin Gönczi, Sächsisch-magdeburgisches Recht in Polen. Untersuchungen zur Geschichte des Rechts und seiner Sprache, IVS SAXONICOMAIDEBVRGENSE IN ORIENTE, 2 (Berlin, 2011), pp. 102-103.

182 See Wacław Uruszczak, 'Commune incliti Poloniae Regni privilegium constitutionum et indultuum: O tytule i mocy prawnej Statutu Łaskiego z 1506 roku' [Commune incliti Poloniae Regni privilegium constitutionum et indultuum: The Title and Legal Validity of Łaski's Statutes (1506)], in: Prace poświęcone pamięci Adama Uruszczaka [Studies in Honour of the Late Adam Uruszczak], eds. Jan Halberda, Michał Hosowicz, and Anna. 
of the Saxon-Magdeburg Law ( 5 non-foliated leaves, after f. 175v); 2) Book I - the Magdeburg Weichbild (f. 176r-197r); 3) Book II - the Sachsenspiegel-Landrecht (f. 197v-239r); 4) provisions of the Lübeck Law (its title separates it clearly from the Sachsenspiegel, but the shift is not indicated by the page header (f. 239r-245r); ${ }^{183} 5$ ) the Sachsenspiegel-Lehnrecht (f. 245v-263r); and 6) Summa legum brevis, levis et utilis by Master Raymundus, with a separate pagination. It is by no means insignificant that Łaski decided to include in his book texts of feudal law (the Sachsenspiegel-Lehnrecht) rather than any of the collections of ortyle. One way of explaining this decision is to point out that a selection of ortyle formed part of the Weichbild and there was no need for more. It is, however, less easy to find any reasons for the inclusion of the Lehnrecht. Admittedly, offices like wójt (Vogt, advocatus) or sottys (Schultheiß, scultetus) could be defined in terms of feudal law, and the jurisdiction over those who held such offices belonged to provincial feudal courts, appropriately named sady leńskie (Lehngerichte). Yet the number of hereditary office-holders in this category had been falling steadily. ${ }^{184}$ taski's choice is all the more puzzling as Konrad of Sandomierz had decided to omit the section on feudal law from his translation. It is estimated that in addition to 12 parchment copies of the Statues, around 150 copies were printed (those that were published in 1507 with a supplement containing statutes (constitutiones) recently adopted by the Sejm). They were to be distributed among provincial courts and cathedral chapters all over Poland. ${ }^{185}$

\subsection{Summary: Destination of Latin Texts of Magdeburg Weichbild}

A review of the state of research on the Latin Weichbild is part of the following discussion of the characteristic features of the individual manuscripts and taski's Commune incliti. In fact, what we know about texts of the Weichbild consists of partial insights that can be gathered from studies of other problems and often surprisingly imprecise information from inventories and catalogues

Karabowicz, (Prace Instytutu Prawa Własności Intelektualnej uJ) 96 (Zakamycze, 20o6), pp. 115-135 For information on earlier research, see the bibliography in this text.

183 Rymaszewski writes: "All the indications suggest that Lübeck Law found its way into taski's collection by chance, due to the scribe's mechanical carrying on with his job of copying a manuscript in which it was so to say concealed". (Rymaszewski, Eacińskie teksty Landrechtu Zwierciadta Saskiego w Polsce. Versio, p. 148).

184 See Ludwik Łysiak, Wtasność sottysia (wójtowska) w Matopolsce do końca XVI wieku [Property of the sołtys (wójt) in Małopolska until the End of the 16th Century] (Kraków, 1964), p. $108 \mathrm{ff}$.

185 Piotr Tafiłowski, Jan Łaski (1456-1531) kanclerz koronny i prymas polski [Jan Łaski (14561531): Grand Chancellor of Poland and Primate of Poland] (Warszawa, 2007), p. 296. Cf. also Potkowski, Ksiażka rękopiśmienna, p. 176. 
of medieval manuscripts. Unfortunately, many manuscripts have been destroyed or lost. In the case of the Sanok Ms, all we have is a helpful description by Emil Kałużniacki. In general, the extant manuscripts can be sorted into the following groups as far as their contents are concerned:

1) Eight manuscripts contain texts of the Saxon-Magdeburg Law only. ${ }^{186}$ The St Petersburg MS consists of two distinct parts; the date of their amalgamation remains unclear. MS Q II 157 is also a composite of two sets of the Saxon-Magdeburg Law, and the time at which they were put together is also unknown.

2) Five manuscripts, each written in a single hand, contain texts of the Saxon-Magdeburg Law and other legislative acts, for example, the municipal laws of Jihlava (the Opatów Ms), canon law (Tomasz of Bydgoszcz's Ms), and Polish land law (the Częstochowa ms, the St Florian ms, the Działyńscy Codex IV).

3) Six manuscripts are made up of blocks which contain texts of diverse provenance, ${ }^{187}$ though in each case, the corpus of the Saxon-Magdeburg Law is a uniform set which predates the volume into which it was bound. This preliminary survey shows that collections that originally included the text of the Saxon-Magdeburg Law alongside other codes of law were an exception. Why the land law block was added to the Częstochowa Ms, the St Florian Ms, and the Działyńscy Codex IV is a matter of speculation. It may also be speculated whether it is somehow connected with their monastic provenance, especially the Częstochowa MS and the St Florian MS ${ }^{188}$ - hence the practical needs of an institution often involved in property litigation. Speculations aside, one thing can be said with great certainty: in practically every case, the Weichbild is accompanied by other collections or codes of the Saxon-Magdeburg Law. This means that the Weichbild was not regarded as the sole and complete source of urban law. Unfortunately, it is impossible to unequivocally identify the sponsors of the great majority of the manuscripts. It is a fair guess, however, that they were owned not only by institutions (e.g. the town councils), but also by individual owners of private libraries that included books of law. ${ }^{189}$

186 They are MS Gn., MS F 143, MS BN 126oo, Q II 157, MS BJ 4405, MS Plesz., MS 951b, and MS Boz.

187 They are ms Kiel., MS BN 126o7, Ms Dział. I, Ms Przem., MS II Q 4, and Ms Warsz.

188 Earlier, of the Abbey of Tyniec near Cracow.

189 Potkowski, Książka rękopiśmienna, pp. 195 and 210. A study by Maria Kramperowa and Witold Maisel of 20 library collections that belonged to Poznań burghers of the second half of 16 th century lists several volumes featuring Saxon-Magdeburg Law, among them Jan Cervus Tucholczyk (2), Bartłomiej Groicki (4), the Sachsenspiegel in German (3), the Sachsenspiegel edited by Paweł Szczerbic (2). See Maria Kramperowa and Witold 
'The Silesian-Małopolska compilation' is an umbrella term which encompasses the German texts of the Weichbild, also known as Konrad of Opole's compilation, and various Latin texts that descended from German sources. The Weichbild of this compilation differs a great deal from the vulgate used in Eastern Germany. The differences result principally from the fact that each branch of the Weichbild developed a dependence on its own source of borrowings. Whereas users of the vulgate had a clear preference for the Sachsenspiegel, the Weichbild community further East found their bearings in Magdeburg's Legal Instructions for Wroctaw (Rechtsmitteilungen Magdeburgs für Breslau) of 1261 and 1295. The near-total absorption of the latter lent the Silesian-Małopolska compilation its distinctive character. The compound name by which I propose to designate this family of texts has the advantage of indicating their origin (Silesia) and the region where they were adopted and modified (Małopolska). The Silesian origin of the compilation is suggested by the fact that the Henryków MS (II F 8), whose Silesian provenance is established beyond any doubt, is closer to the original Weichbild than the Cracow City Council Ms (BJ 169), attributed to Konrad of Opole. The extraordinary similarity of those two texts indicates that they must have a common base. The key texts of the Silesian-Małopolska compilation are contained in two groups of manuscripts. The first set includes the Cracow Ms, the Henryków Ms, the Baworowscy Ms, and the Żagań ms; the second is made up of the German-language the Wawel Ms used by the High Court of German Law at Wawel and a compilation shelfmarked BJ 170a. The latter has certain characteristics that exclude their complete dependence on the Weichbild known from the other four manuscripts. These features appear not only in the aforementioned articles and compilations; in many cases, they are closer to the original sources of the Weichbild than the Cracow Council manuscript or the Henryków Ms. There is also additional evidence that points to the links between the Wawel Ms and MS BJ 170a and a text characteristic of Cracow MS - a fact which proves the impact of that manuscript or a text very close to it on the wording of the Weichbild in the Wawel MS and MS

Maisel, "Księgozbiory mieszczan poznańskich drugiej połowy XVI w". [Library Collections of Poznań Burghers of the Second Half of the 16th Century], Studia i Materiaty do Dziejów Wielkopolski i Pomorza 11/1 (1960), 304, 305, and 307. Cf. "Law Books During the Transition from Late-Medieval to Early-Modern Legal Scholarship", in: The Formation and Transmission of Western Legal Culture. 150 Books that Made the Law in the Age of Printing, Serge Dauchy, Georges Martyn, Anthony Musson, Heikki Pihlajamäki, Alain Wijffels, eds., Naoko Seriu, coop. (Studies in the History of Law and Justice) 7, series eds. Georges Martyn, Mortimer Sellers (New York - Berlin - Heidelberg, 2016), pp. 18-19. 
BJ 170a. Whereas these two manuscripts contain just two different variants of the German text, the other four texts underwent an evolution which consisted of the addition to the received text of a selection of Magdeburg ortyle in the Baworowscy Ms and the Żagań Ms. The Baworowscy ms contains a Weichbild which is clearly dependent on the Cracow Council manuscript, and its assortment of the ortyle is of Cracow provenance. Moreover, both the Baworowscy and the Żagan manuscripts are bilingual: Latin and German. This means that the ortyle were added to both versions of the Weichbild independently from each other - that is, it can be ruled out that it affected the Latin Weichbild first.

However, it was the Latin rather than the German Weichbild that became more popular in the Kingdom of Poland, if the proportion of extant manuscripts in either language are anything to go by. At the same time, it may be surmised that a great deal more manuscripts have been lost, as those that have survived are parts of blocks which include other legal texts such as the Sachsenspiegel, Polish land law, or canon law. A close study of those volumes shows that in many of them, each section was written in a different hand, which could indicate that they were made up of heterogeneous manuscripts. Blocks of monastic provenance, like the Częstochowa MS or the St Florian MS, which contained texts of the municipal law and Polish land law, were written in one hand. However, manuscripts of the Magdeburg Law seem to have functioned as separate units, dedicated to the needs of the urban communities and their legal practice. Unfortunately, the evidence is too scant to decide whether they were used in municipal courts (with the exception of Cracow MS and Pleszew Ms, which surely were used in such a way, and the Przemyśl ms, which probably was); whether they were used in High Courts of German Law (like the Wawel Ms); or whether they were simply private property. 


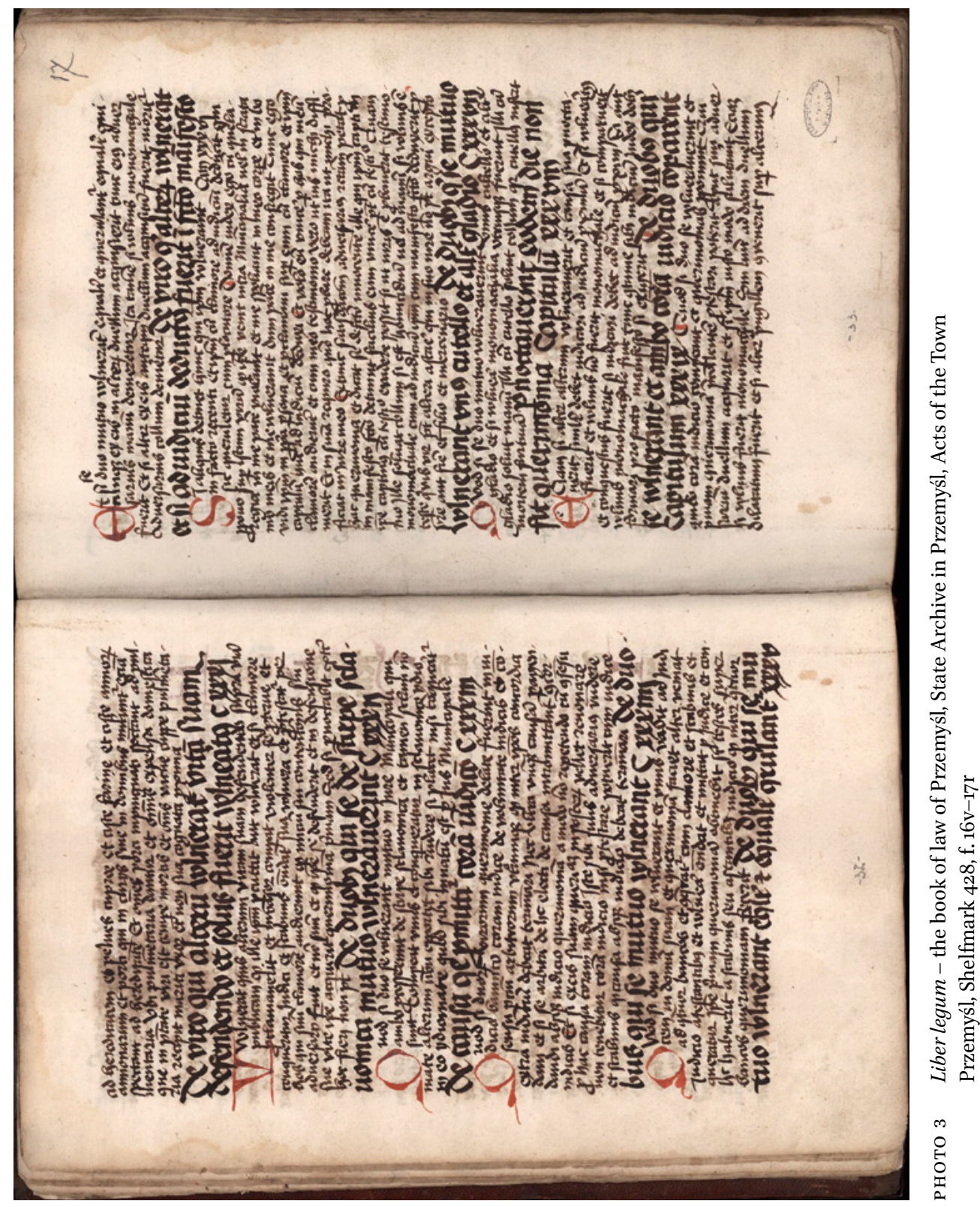




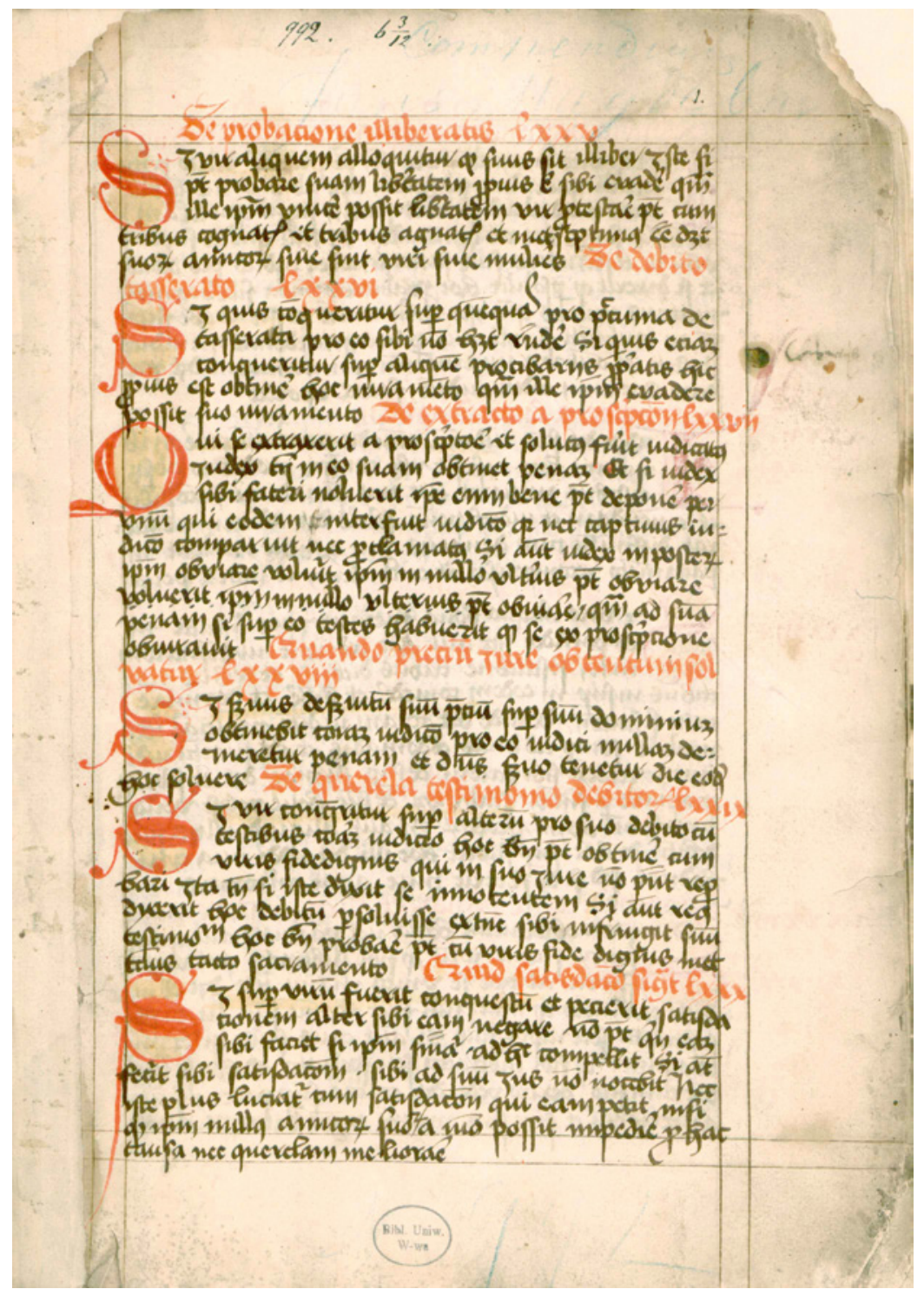

Рното 4 Warsaw manuscript, University of Warsaw Library, Shelfmark 5 , f. ir 